\title{
Genesis, Neurotrophin Responsiveness, and Apoptosis of a Pronounced Direct Connection between the Two Eyes of the Chick Embryo: A Natural Error or a Meaningful Developmental Event?
}

\author{
Solon Thanos \\ Department of Experimental Ophthalmology, School of Medicine, University of Münster, D-48149 Münster, Germany
}

Unilateral intraocular injections of either of two fluorescent carbocyanine dyes into the embryonic chick eye resulted in both retrograde staining of ganglion cells (GCs) in the eye contralateral to site of injection and anterograde labeling of axons whose cell bodies were located within the injected eye. This prominent retino-retinal projection formed by thousands of GCs having a nasal origin and temporal termination appeared at embryonic day 6 (E6), attained its maximum intensity at E13-E14, and gradually disappeared until E18. The axonal growth cones ended superficially and never penetrated deeper layers of the retina. Treatment of the projection with BDNF resulted in massive terminal branching of the axons within deeper layers of the target retina. Double injection into the eye and the isthmo-optic nucleus showed a concomitant ingrowth of axons in the contralateral retina. Individual GCs died be-

The diversity of connections formed by a particular area of CNS during development is more extensive than that observed in the mature nervous system. Some areas are transiently connected with regions and subregions that do not belong to their normal functional circuits. In addition to axons that project erroneously within a particular target area, aberrant connections with "nontarget" areas have been described in the developing CNS (Innocenti, 1981; McLoon and Lund, 1982; Cowan et al., 1984; O'Leary and Terashima, 1988; Nakamura and O'Leary, 1989; Simon et al., 1994). Such projections occur predominantly in areas connecting related anatomical regions, such as the decussation of retinal axons at the chiasm (Silver, 1984; Halfter, 1987; Sretavan, 1990; Drenhaus and Rager, 1994), the crossing of cortical axons at the midline (Koester and O'Leary, 1994), and the crossing of ascending spinal and descending corticospinal fibers at the level of brainstem in the pyramidal tract (for review, see O’Leary et al., 1994). Most investigations ascribe no particular function to fibers entering inappropriate pathways and nontarget areas, because most of the cells die during development. Such

Received Oct. 13, 1998; revised Jan. 26, 1999; accepted March 2, 1999.

This work was supported by Deutsche Forschungsgemeinschaft Grants DFG Th 386/7-1 and 9-1. Initial stages of the work concerning the guidance of isthmo-optic axons to the retina were completed with the assistance of Dr. D. D. M. O'Leary, whose suggestions and critical ideas are greatly acknowledged. I thank Ilka Manig for technical assistance, Stefanie Gögel for help with preparing the camera lucida drawings of Figure 4, Magdalena Pinheiro for typing this manuscript, and Marliese Wagener and Susane von der Heide for the photographic work. Drs. Evan Dreyer, Rita Naskar, and David Kim-Aun are acknowledged for critical comments on this manuscript.

Correspondence should be addressed to Solon Thanos, Department of Experimental Ophthalmology, School of Medicine, University of Münster, Domagkstraße 15, D-48149 Münster, Germany.

Copyright (C) 1999 Society for Neuroscience $\quad 0270-6474 / 99 / 193900-18 \$ 05.00 / 0$ tween E9 and E13, but massive apoptotic cell death was mainly monitored at E14 and later. Disintegrated cells showed typical images of apoptosis. Because degenerating cells were prelabeled with the membranophilic fluorescent carbocyanine dye, their death allowed the concomitant visualization of phagocytosing cells, too. Radial Müller glia were the only class of cells observed to become phagocytotic between E9 and E16. These cells became replaced exclusively with microglial cells from E17 on. The results suggest that the topologically restricted retinoretinal projection may have some developmental significance rather than representing a massive erroneous projection. Most likely, the projection may serve as a "template" to guide centrifugal isthmo-optic axons into the retina.

Key words: retinal GCs; retino-retinal projection; chick development; programmed cell death; fluorescent dyes; vision projections are considered products of misguidance attributable to the failure of the molecular mechanisms of pathfinding. Part of this failure of guidance may also be seen in the appearance of so-called "waiting periods" at decision points such as the chiasm (Navascués et al., 1987; Sretavan, 1990; Guillery et al., 1995), the cortical subplate (for review, see O'Leary et al., 1994), and the hippocampal-fimbria-fornix system (Del Rio et al., 1997).

Also, the eyes of higher vertebrates do not usually communicate via direct neuronal projections. However, a direct retinoretinal projection formed by few ganglion cells (GCs; 12) has been described in different anuran species both at juvenile stages and in adulthood (Toth and Straznicky, 1989). Substantially more GCs with predominant location within the temporoventral retinal periphery were traced in the frog regenerating visual system (Bohn and Stelzner, 1981a). Anterograde tracing with HRP in the same system indicated that the axonal tips of these cells were found within the contralateral optic nerve but failed to reach the contralateral retina (Bohn and Stelzner, 1981b). During development, a small retino-retinal projection was traceable with HRP between embryonic day 16 (E16) and E21 in hooded and albino rats and disappeared shortly after birth (Bunt and Lund, 1981). By using more-sensitive fluorescent tracing, Müller and Holländer (1988) described the persistence of a small component of this projection beyond juvenile stages and showed that some of these cells have an axon collateral projecting to the superior colliculus. The fact that not all retino-retinally projecting cells die was attributed to the collateral axons in the brain (Tennant et al., 1993). The development and disappearance of such a projection to the contralateral optic nerve $(\mathrm{ON})$ was also examined in the embryonic chick, and it was concluded that the lack of strong 


\begin{tabular}{|c|c|c|c|c|c|c|}
\hline \multirow[b]{2}{*}{ Age } & \multicolumn{3}{|c|}{ Ganglion cell bodies } & \multirow[b]{2}{*}{ Axons } & \multirow[b]{2}{*}{ Microglia } & \multirow[b]{2}{*}{ Müller cells } \\
\hline & Vital & With dendrites & Apoptotic & & & \\
\hline \multirow[t]{5}{*}{ E6 } & 7 & None & None & 4 & None & None \\
\hline & 11 & None & None & 17 & None & None \\
\hline & 5 & None & None & 20 & None & None \\
\hline & 22 & None & None & 3 & None & None \\
\hline & 20 & None & None & 7 & None & None \\
\hline \multirow[t]{5}{*}{ E9 } & 39 & 13 & None & 66 & None & ND \\
\hline & 52 & 5 & 1 & 60 & None & ND \\
\hline & 50 & 22 & None & 74 & None & ND \\
\hline & 61 & 20 & 2 & 19 & None & ND \\
\hline & 27 & 12 & 1 & 14 & None & ND \\
\hline \multirow[t]{6}{*}{ E14 } & 756 & 600 & 800 & 512 & None & 67 \\
\hline & 111 & 92 & 176 & 37 & None & 210 \\
\hline & 1140 & 902 & 1203 & 900 & None & ND \\
\hline & 800 & 512 & 1100 & 207 & None & ND \\
\hline & 117 & 92 & 163 & 125 & None & ND \\
\hline & 1300 & 1200 & 907 & 56 & None & 27 \\
\hline \multirow[t]{5}{*}{ E16 } & 26 & 26 & 116 & 63 & 11 & ND \\
\hline & 50 & 50 & 300 & 17 & None & ND \\
\hline & 10 & 10 & 76 & 3 & None & ND \\
\hline & 21 & 21 & 112 & 27 & 37 & 7 \\
\hline & 6 & 6 & 76 & 2 & 30 & 19 \\
\hline \multirow[t]{5}{*}{ E18 } & 1 & 1 & 17 & 1 & 305 & None \\
\hline & None & None & 3 & None & 1105 & 37 \\
\hline & 3 & 2 & 21 & None & 300 & ND \\
\hline & 1 & 1 & 10 & None & 802 & ND \\
\hline & None & None & 6 & None & 700 & 33 \\
\hline \multirow[t]{3}{*}{ P11 } & None & None & None & None & None & None \\
\hline & None & None & None & None & None & None \\
\hline & None & None & None & None & None & None \\
\hline
\end{tabular}

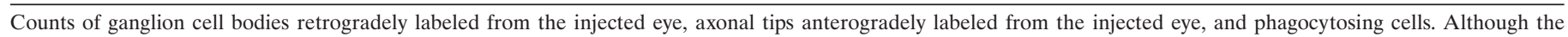

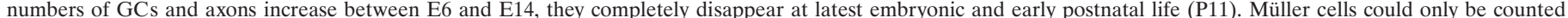

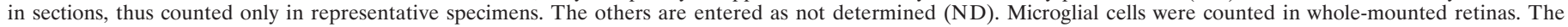
ganglion cell populations were subdivided into vital cells (as far as deducible from morphology) and dead cells showing typical apoptotic changes.

directional information within the ON was responsible for its disappearance (Halfter, 1987).

The present work was undertaken to label and analyze some unknown aspects of the retino-retinal projection in the chick embryo during development.

\section{MATERIALS AND METHODS}

Labeling of the projection. Fertilized brown Leghorn chicken eggs were incubated for $72 \mathrm{hr}$ at $60 \%$ humidity and temperature of $38^{\circ} \mathrm{C}$ with occasional turning. From this stage on, the embryos were removed from their eggshell and transferred to Petri dishes for further incubation, as introduced for neuroanatomical tracing by Thanos and Bonhoeffer (1984, 1987). Such embryos grow normally and correspond to the stages of Hamburger and Hamilton (1951) at given embryonic days of ontogenesis. Thus, embryonic days will be referred to throughout this paper. At various stages of development the extraembryonic membranes were opened with microsurgical scissors above one eye, and depending on the embryonic stage, 3-10 $\mu \mathrm{l}$ of either the fluorescent dye 1,1'-dioctadecyl$3^{\prime}, 3^{\prime}, 3^{\prime}, 3^{\prime}$-tetramethyl carbocyanine perchlorate (DiI, D282; Molecular Probes, Eugene, OR), or 4-(4-dimethylaminostyryl)- $N$-methylpyridiumiodide (4DI-10ASP, D291; Molecular Probes), diluted in ethanol at 1 $\mathrm{mg} / \mathrm{ml}$, was injected into the vitreous body by means of pulled glass capillaries with a tip diameter of $20-50 \mu \mathrm{m}$. The embryos were returned to the incubator and incubated further for $4 \mathrm{~d}$. Hatched chicks $(n=3)$ from the same strain were used to study whether the projection persisted after hatching. They were anesthetized with ether inhalation at post- hatching day $6,10 \mu \mathrm{l}$ of $2 \% 4 \mathrm{Di}-10 \mathrm{ASP}$ was injected into left eye intravitreally, and they were killed at posthatching day 11 .

To study whether the same cells project both into the contralateral retina and to the optic tectum, 15 embryos were used for double labeling from these areas. For this, the fluorescent tracer Fluorogold (fluorochrome; for review, see Thanos et al., 1994) was injected as a $2 \%$ aqueous solution into the left optic tectum, and 4Di-10ASP was injected into the left eye at E10. The contralateral retina was analyzed at E14-E15 to detect double-stained GCs by using the corresponding microscope filters. To study whether retino-retinal axon ingrowth matches developmentally with ingrowth of isthmo-optic axons, either of the carbocyanine dyes DiI and 4Di-10ASP was injected into the area of the left isthmo-optic nucleus at E6. The other dye was injected into the left eye at the same age, and the right retinas of the embryos were analyzed for axonal ingrowth at E9 or later.

Because GCs are sensitive to neurotrophic effects of brain-derived neurotrophic factor (Johnson et al., 1986; Herzog and von-Bartheld, 1998), 1-3 $\mu \mathrm{g}$ of BDNF (Preprotech, London, England) was co-injected with the fluorescent dye 4Di-10ASP (into the right eye) at E9 $(n=16)$ to study anterograde effects on the axonal tips entering the partner eye and retrograde effects on the ganglion cell bodies projecting axons into the injected eye. In a second group of 12 embryos (E9), BDNF was injected into the right eye, and concomitantly 4Di-10ASP was injected into the left eye. This experimental setup allowed the visualization of the direct effects on both the terminating axonal tips and the ganglion cell bodies within the right eye. The embryos of both groups were analyzed at E14, E16, and E18. 

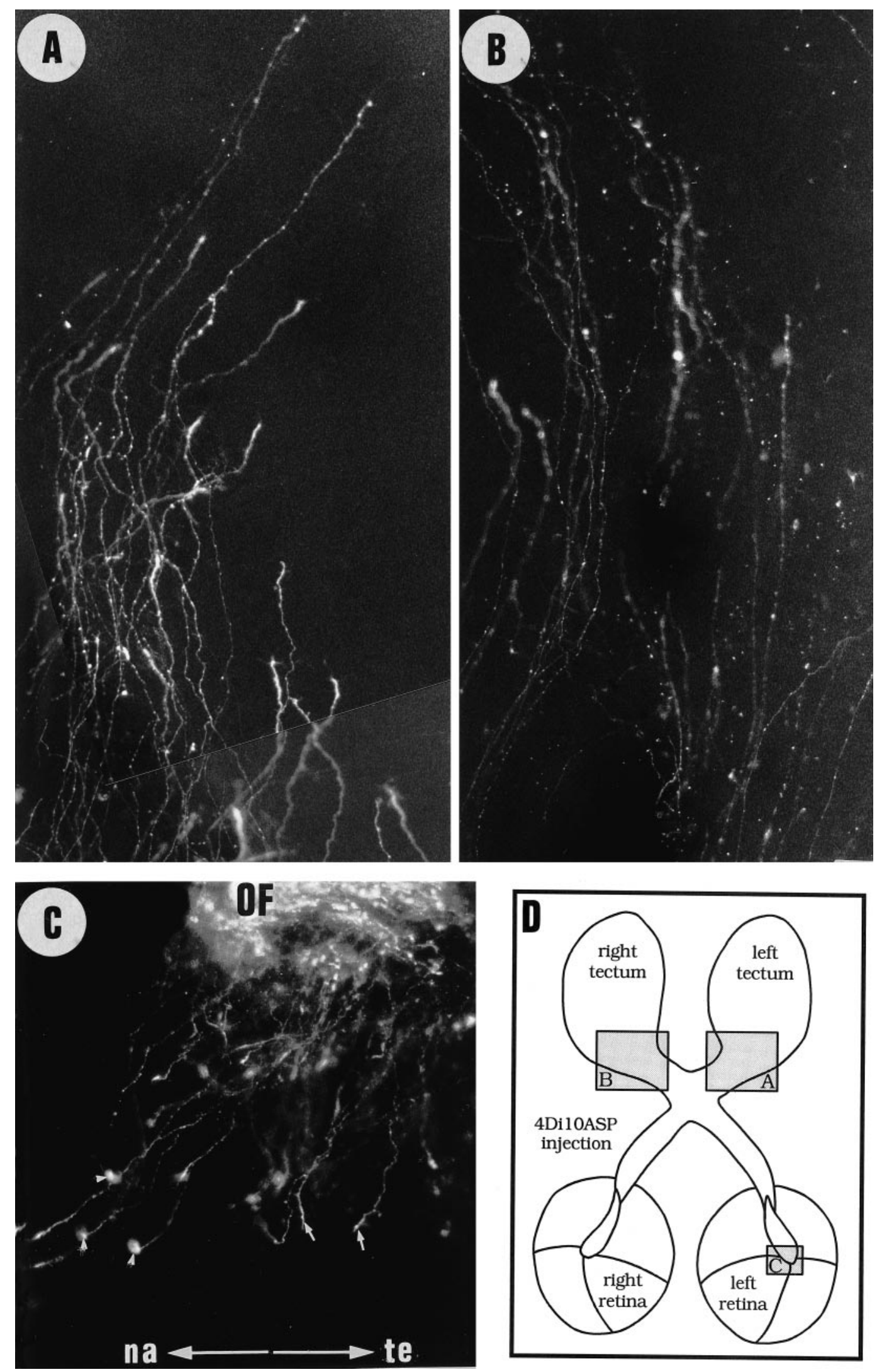

Figure 1. Labeling of the retino-fugal axons shows the major components of the chick visual system projections, as indicated in the schematic $(D)$. Injection of 4Di-10ASP into the right eye at E4 resulted in anterograde labeling of axons in the anterior pole of the left tectum ( $A$ corresponds to intersection $A$ of the diagram in $D$ ). As expected from former studies (O'Leary et al., 1983, Thanos and Bonhoeffer, 1984), axons were also labeled in the anterior pole of the ipsilateral tectum $(B)$. $C$, Anterograde staining of axons (arrows) that terminate in the noninjected contralateral retina and of cell bodies (arrowheads) whose axons have reciprocally projected into the injected right retina. The optic fissure $(O F)$ at the (Figure legend continues) 
Tissue processing and analysis. The embryos or young chicks were killed, and their retinas and brains were immersion-fixed in $4 \%$ paraformaldehyde in $0.1 \mathrm{M} \mathrm{PBS}, \mathrm{pH} 7.2$, at $4^{\circ} \mathrm{C}$ for $1-2 \mathrm{~d}$. At the beginning of fixation, radial cuts were made in the retinas to facilitate flattening on nitrocellulose filters (Sartorius, Goettingen, Germany) and glass slides. The success of injection was monitored by viewing the whole-mounted contralateral tecta, which were divided into halves by cuts along the rostrocaudal axis. Only the contralateral retinas with complete anterograde labeling of the corresponding retino-tectal projection were considered to have all GCs labeled and were included in the present analysis. Whole mounts of either retinas or tectal halves were prepared on glass slides in Mowiol (Hoechst, Frankfurt, Germany). The tissues were examined using fluorescence optics on a standard microscope (Axiophot; Zeiss, Thornwood, NY). The outlines of the retinal whole mounts were drawn using a camera lucida tube (Zeiss) attached to a dissecting microscope. The retinal areas containing either retrogradely labeled GCs and/or anterogradely filled axons were indicated on the camera lucida drawings at a magnification 5 or $10 \times$ on the fluorescence microscope. The absolute numbers of retinal GCs and axons at later stages of development were counted under the fluorescence microscope at a magnification of $20 \times$, and representative specimens were photographically documented with black-and-white negative film.

Monitoring of cell death and phagocytosis. Because the carbocyanine dyes used are best suited to monitor the events of ganglion cell death and their subsequent clearance by phagocytosis (for review, see Thanos et al., 1994), apoptotic cell death of retrogradely labeled neurons could be assessed and analyzed throughout the development and disappearance of the retino-retinal projection. Individual dying GCs were observed at various embryonic stages in whole mounts and sections. The total number of GCs with intact cell bodies and dendritic arbors was determined by viewing the total retinal surface. In the same manner, cells with collapsed cell bodies, degenerated dendrites, and apoptotic debris were determined at certain stages of development. Phagocytosing microglial cells were also identified by their typical ameboid or ramified morphologies (quail, Navascués et al., 1994, 1995; rat, Thanos et al., 1994) and counted in the same whole mounts. The absence of microglial cells at earlier stages of cell death (see Results) implies the involvement of other types of cells in the early phagocytosis. For this purpose, sections of some specimens were prepared to detect phagocytotic cells such a Müller glia, which could be identified by the fluorescent dyes they had ingested from the dying cells. Mapping of the intraretinal location of either growth cones or GCs was done in retinal whole mounts spread on glass slides and drawn with a camera lucida device attached to a microscope.

\section{RESULTS}

\section{Early development of the retino-retinal projection}

After the injection of either of the dyes DiI or 4Di-10ASP, most of the embryos $(>80 \%)$ tolerated the injection, and the injected eyes had normal sizes after decapitation, indicating that neither of the dyes was oculotoxic. Examination of tecta revealed a complete staining of the retino-tectal projection in $>90 \%$ of the cases, thus indicating that the retino-retinally projecting contingent of cells should be labeled too. Embryos lacking an intact retino-tectal pathway were discarded from further analysis. Embryos injected at E4 and analyzed at E6 showed a small number of anterogradely filled axons. Their numbers varied but were consistently observed in all embryos (Table 1). As an extension of the work of Halfter (1987), who had monitored this projection with fluorescent dextran amines within the chiasm and $\mathrm{ON}$ at early stages of its development, individual axons could be visualized along their entire length until their intraretinal trajectory. Figure 1 shows a representative embryo (of the nine injected at E4 and killed for analysis at E6) in which both retino-fugal projections to the contralateral (Fig. 1A) and ipsilateral (Fig. 1B) tectum were intensely labeled. In addition, a comparably large number of axons grew into the contralateral eye (Fig. 1C). In contrast to both retino-tectal projections with clearly visible growth cones as indicators of successful anterograde transport (Fig. $1 A, B$ ), the retino-retinal projection consists of both anterogradely filled growth cones and retrogradely labeled ganglion cell bodies of the reciprocal projection to the injected eye (Fig. 1C).

Three days later (E9), several axons have grown over long distances within the retina (Fig. $2 A, B$ ), whereas the numbers of cells projecting long axons increased to reach a maximum density at E13-E14 (Fig. 2C). At all stages investigated, axonal growth cones were heavily loaded with the fluorescent dye (Fig. 2D-G) and neither branched nor extended multiple processes or terminal branches. All individual growth cones studied were localized within the optic fiber layer and virtually never entered deeper layers of the retina. Terminal arborizations such as those found in the optic tectum were never observed within the retino-retinal projection. Morphologically, the growth cones were "spearshaped" and simply organized with few apically oriented filopodial protrusions and no signs of extensive arborizations or side branches, which are typical for retino-fugal axons growing on the tectal surface (Thanos and Bonhoeffer, 1987; Nakamura and O'Leary 1989). In this context, retino-retinal axon morphology differs from that of retino-tectal axons and from that of isthmoretinal fibers (Fig. 3C-E), perhaps indicating that these axons grow toward a "wrong" direction or lack target-derived information or sufficient neurotrophic influence.

\section{Simultaneous ingrowth of retino-retinal and isthmo-optic fibers}

The isthmo-optic nucleus (ION) innervates the contralateral retina by axons after a transient retino-fugal projection along the medial tectal margin (O'Leary and Thanos, 1985). In the seven embryos with DiI-labeled retino-retinal axons from the left retina and 4Di-10ASP-labeled isthmo-optic axons from the left ION, both populations appeared closely intermingled in the right retina. When studied at E9, both green (Fig. 3A) and red (Fig. 3B) axons were located within the OFL. Also at later stages of development both axonal populations are mixed within the OFL. However, in contrast to the retino-retinal fibers, the isthmo-optic axons appeared to penetrate deeper retinal layers and to form initial terminal branches from E11-E12 on (Fig. $3 F$ ). Another difference between retino-retinal and isthmo-retinal axons consists in the morphology of growth cones, with the isthmo-retinal growth cones possessing multiple filopodia (Fig. $3 C-E$ ).

\section{Effects of BDNF on the retino-retinal projection}

To study the susceptibility to neurotrophic factors and to analyze the pattern of retinal innervation, BDNF was injected either into the same eye with 4Di-10ASP (Fig. 4A) or into the eye contralateral to dye injection. Most of the embryos, which received BDNF plus 4Di-10ASP and were analyzed at E14-E18, survived the injections. The group of embryos, which received both substances in the same eye (Fig. 4A), exhibited a remarkable branching of anterogradely filled axons monitored in the contralateral retina (Fig. 4B-E). In addition, the growth cones showed lateral sprouts and multiple filopodial protrusions (Fig. $3 F$ ) when compared with

$\leftarrow$

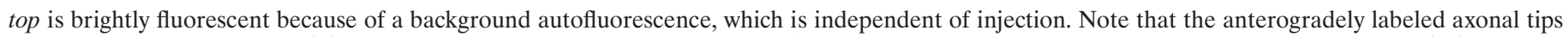

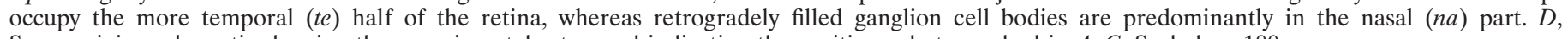
Summarizing schematic showing the experimental setup and indicating the positions photographed in $A-C$. Scale bar, $100 \mu \mathrm{m}$. 

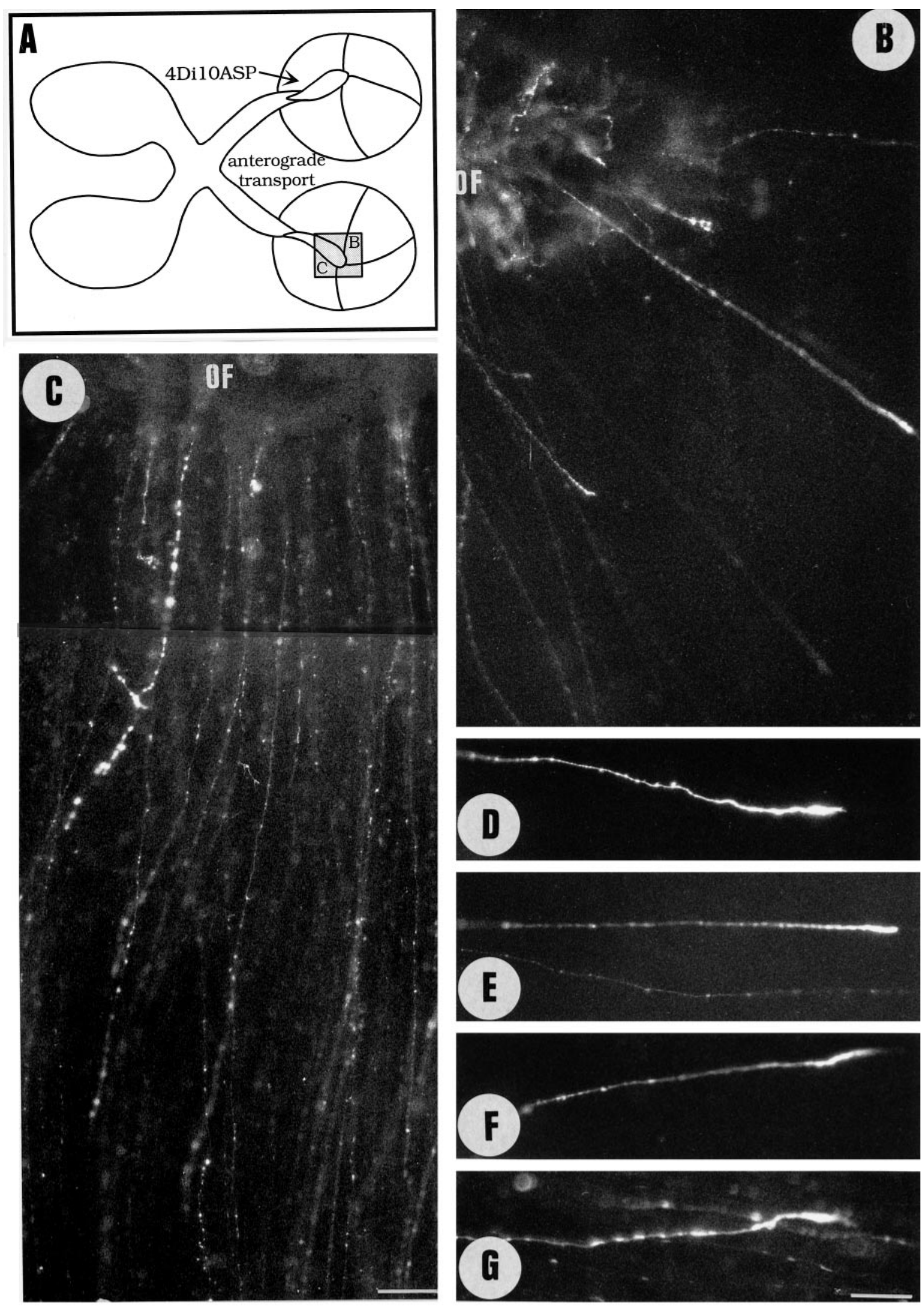

Figure 2. Anterograde labeling of axons in the retino-retinal projection. $A$, Schematic showing that injection of 4DiI-10ASP into the left eye labels the axons entering the temporal contralateral retina. The intersections at the left optic fissure $(O F)$ indicate the location of $B-D$. $B$, Axons projecting from the $O F$ toward the peripheral retina at E9. $C$, Large number of axons extending from the $O F$ toward the temporal retinal periphery. $D-G$, Higher magnifications of axonal tips showing the typical growth cones within the retina contralateral to the dye injection. Scale bars: $B, C, 50 \mu \mathrm{m} ; D-G, 25 \mu \mathrm{m}$. 

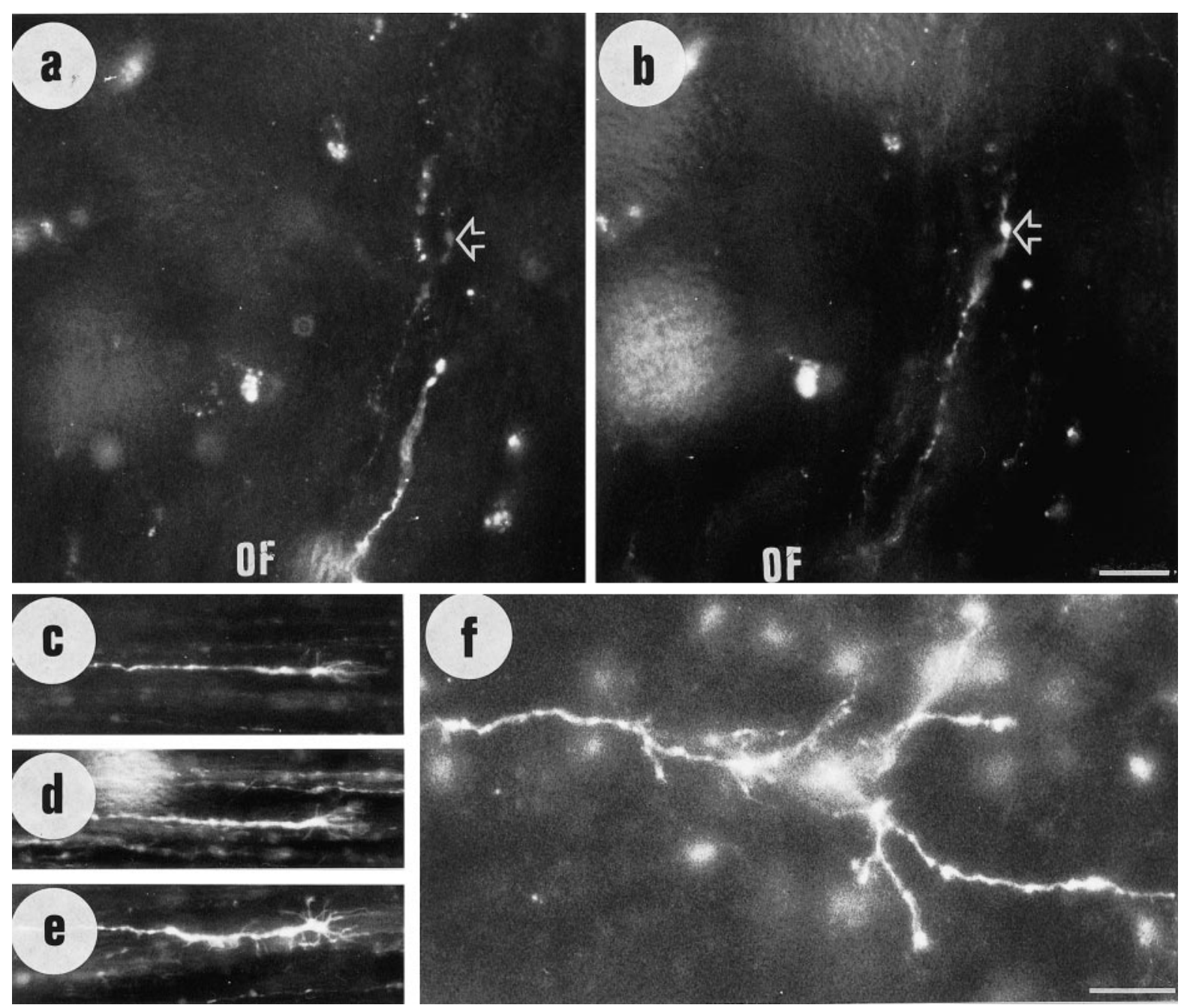

Figure 3. Anterograde labeling of retino-retinal $(A)$ and isthmo-retinal $(B)$ axons in the flat-mounted right retina at E9. The photographs show the same retinal region close to the optic fissure $(O F)$. Two of the retino-retinal axons $(A)$ and one isthmo-optic axon $(A, B$, arrows) are in close vicinity to each other but are directed toward the retinal periphery. $C-E$, Typical intraretinal growth cones of isthmo-retinal axons labeled wtih 4Di-10ASP at E6 and observed in the whole-mounted retina at E9. Note the multiple filopodial protrusions. $F$, Typical isthmo-retinal terminal branching labeled with 4Di-10ASP at E6 and photographed at E13. Scale bars, $25 \mu \mathrm{m}$.

the nontreated growth cones of Figure $2 D-G$. The ganglion cell bodies of the left retina showed normally configured dendritic shapes. In the group of embryos that received BDNF and dye in either of the eyes, no direct effects were evident on the axonal tips entering the BDNF-treated eye. Such dramatic effects could not be obviously monitored on the dendritic branching patterns, which were more complex and elaborated than in the normal retina. A quantification of the effects of BDNF on axonal branching is shown in Figure 5. At the three stages analyzed, BDNF had significant effects on the proportion of axons, which formed terminal branches, when being injected into the eye of origin but not when injected directly into the eye of termination. The results show that GCs respond to BDNF in a differential way depending on the side of injection. The responsiveness of the cell bodies influences the axonal tips anterogradely and is responsible for the ability of axons to clearly penetrate the partner retina and form terminal branches.

With respect to retinal topology, the number of retrogradely labeled GCs and their localization were determined from wholemounted retinal tissue at different stages of development. Embryos injected at E6 and analyzed at E9 showed retrogradely labeled GCs, in addition to the anterogradely filled axons. Also, all embryos injected at E10 $(n=10)$ and analyzed at E14 had typical retrogradely filled GCs (Figs. 6, 7). Most of the cells were located within the nasal retina (Fig. 6), whereas fewer individual cells were also scattered throughout the entire retinal surface (Fig. 6B-F). The patterns of cell distribution and number of cells did not differ between noninjected and BDNF-treated embryos. Although the total numbers of labeled cells varied, the patterns of distribution were consistent, as shown in Figure 6. In some cases, the density within the nasal peripheral retina (Fig. 7A) approached $620 \mathrm{GC} / \mathrm{mm}^{2}$, indicating that a substantial proportion of GC in this area sent their axons into the contralateral retina. A quantitative presentation of retrogradely filled GCs and anterogradely labeled axons is shown in Table 1.

\section{Ganglion cell death within the retino-retinal projection}

In the visual system of various vertebrates studied so far, overproduced GCs die during late embryonic and early postnatal development (O'Leary et al., 1983). In particular, GCs contributing to erroneous projections such as the ipsilateral retino-tectal projection die (McLoon and Lund, 1982; O'Leary et al., 1983; 

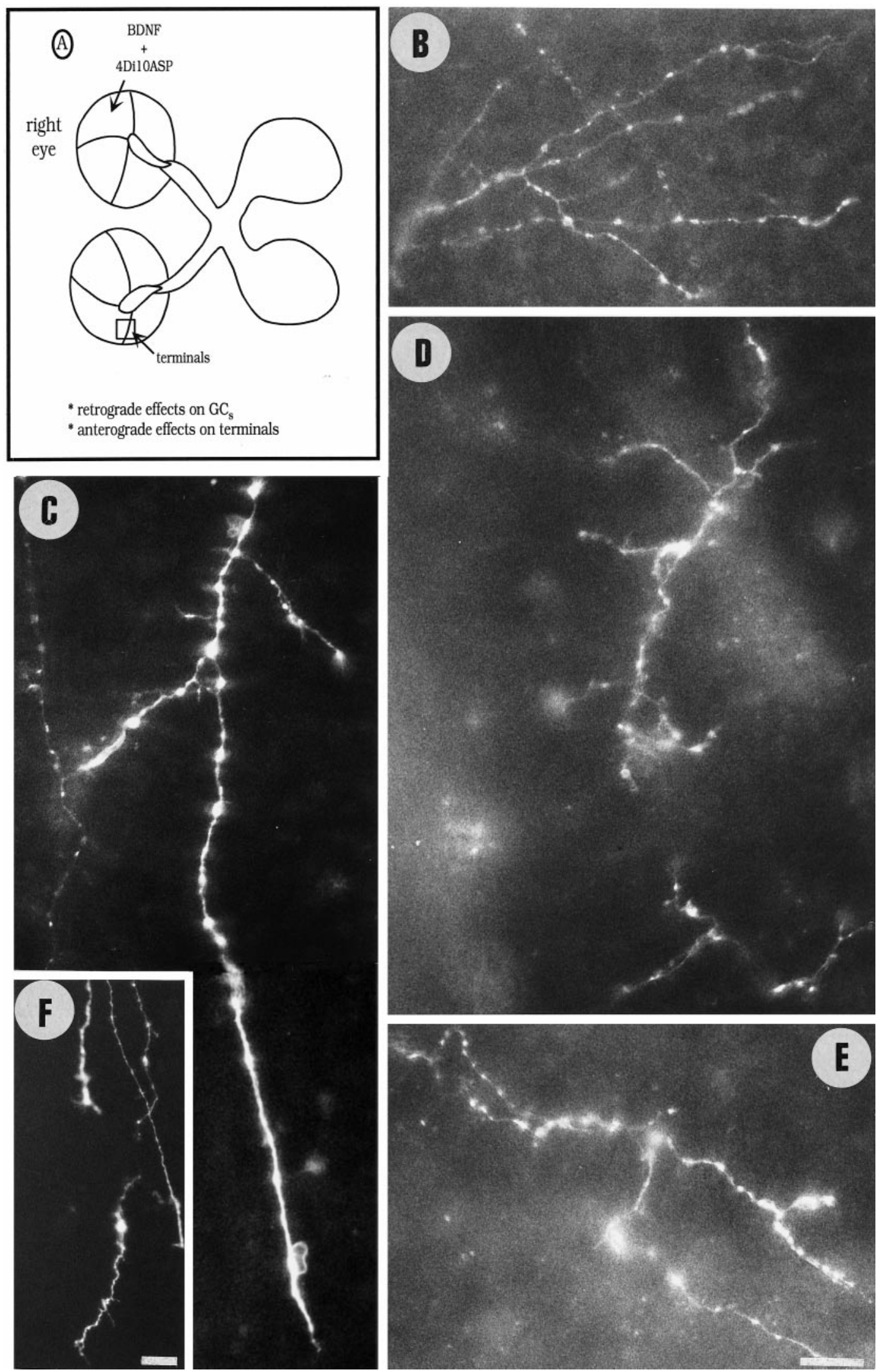

Figure 4. Fluorescence photomicrographs showing representative terminal arborizations of retinal axons within the target retina contralateral to the site of BDNF and dye injection at E16. $A$, Schematic showing the co-injection protocol of BDNF and 4Di-10ASP to visualize retino-retinal terminals. The retrogradely affected ganglion cell is shown in Figure $11 F . B-E$, Retino-retinal terminals within the optic fiber layer $(B)$, within the ganglion cell layer $(C)$, and within the inner plexiform layer $(D, E)$. The terminals possess several branches with multiple varicosities. $F$, Filopodial growth cones within the optic fiber layer. Scale bar, $25 \mu \mathrm{m}$. 


\section{Effects of BDNF on axonal branching}

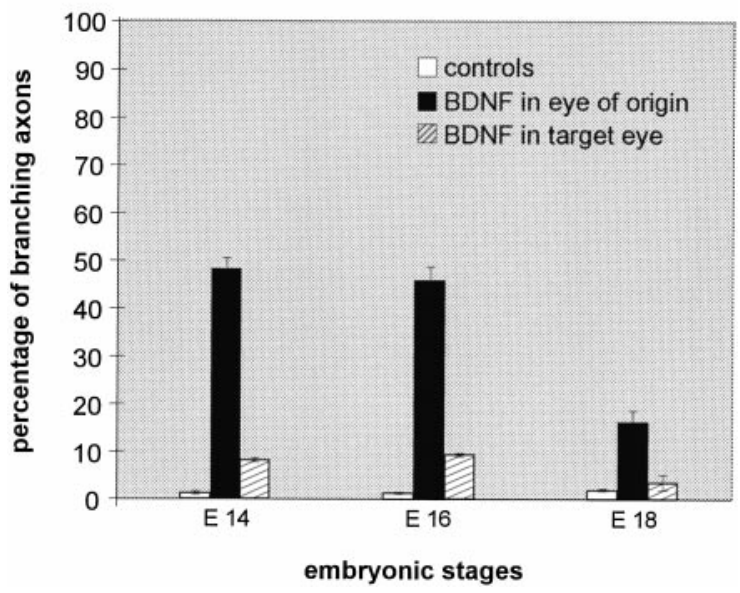

Figure 5. Graphic representation of the axonal tips that form branches within the retina under control and BDNF conditions. There is virtually no arborization without BDNF $(1.2 \pm 0.6 \%)$ and little arborization when BDNF was injected into the target eye $(8.1 \pm 0.7 \%)$. Approximately half of the axons $(48.0 \pm 4.5 \%)$ formed elaborate branches within deeper layers when BDNF was injected into the eye of origin (compare with Fig. $4 A$ ). Despite BDNF treatment, cell death eliminated most of the terminals at E18. The differences between treated and nontreated embryos were highly significant at the 95\% confidence level (two-tailed Student's $t$ test).
Thanos and Bohnoeffer, 1984), and those fibers overshooting onto ectopic contralateral positions degenerate (Nakamura and O'Leary, 1989). In accordance with these and numerous other observations within the developing CNS, it is to be expected that cells contributing to the retino-retinal projection become eliminated, too. Indeed, the different stages of apoptosis could be monitored in the present study, because the cells were loaded with membranophilic carbocyanine dyes that result in phagocytosis-dependent labeling of cells clearing away the degeneration products (for review, see Thanos et al., 1994).

First morphological indications of cell death were obtained at E9-E10 with individual cells showing irregular staining and atypical morphologies. The number of dying cells per retina increased until E14, when approximately half of all labeled GCs displayed condensed nuclei and disintegrated somata as signs of apoptosis. Some typical apoptotic GCs are shown in Figure 7, $A$ and $B$. Larger magnification enabled observation of the different stages of dying cells (Fig. 7C), with multiple apoptotic remnants at final stages of death (Fig. 7D). The simultaneous visualization of vital and dying GCs on the same retinal whole mounts permitted the quantification of these cells and the process of decay (Table 1). The proportion of dying neurons increased between E14 and E16 (Fig. 8), resulting in almost complete disappearance of living GCs at E18 (Fig. 8). In the groups of BDNF-treated embryos cell death was slightly delayed, with more cells and healthy dendrites visible at E16 (Fig. 8). However, almost no stained cells were observed at E18 (Fig. 8), indicating that BDNF does not rescue the cells beyond the period of programmed cell

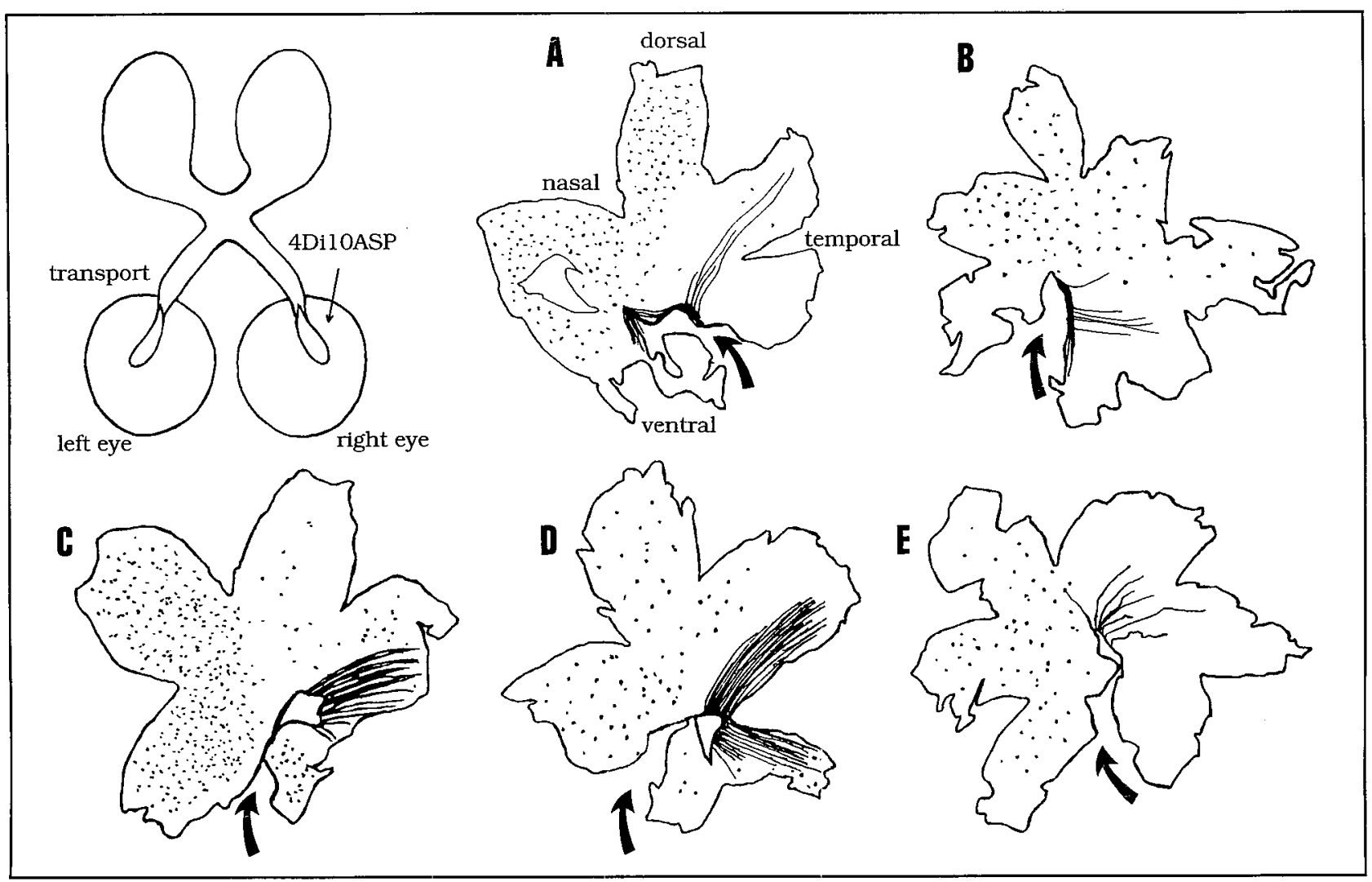

Figure 6. Camera lucida drawings of flat-mounted retinas showing the setup of the experiment $(A)$ and five examples with injection performed at E10 and analyzed at E14 $(B, D, E)$ and E16 $(C, E)$. The dotted area indicates the location of retrogradely filled ganglion cell bodies, whereas lines indicate anterogradely labeled axons from the injected retina. Note that the cells are located predominantly within the nasal hemiretina, and axons are located within the temporal hemiretina. The arrow points to the ventrally located optic fissure. 


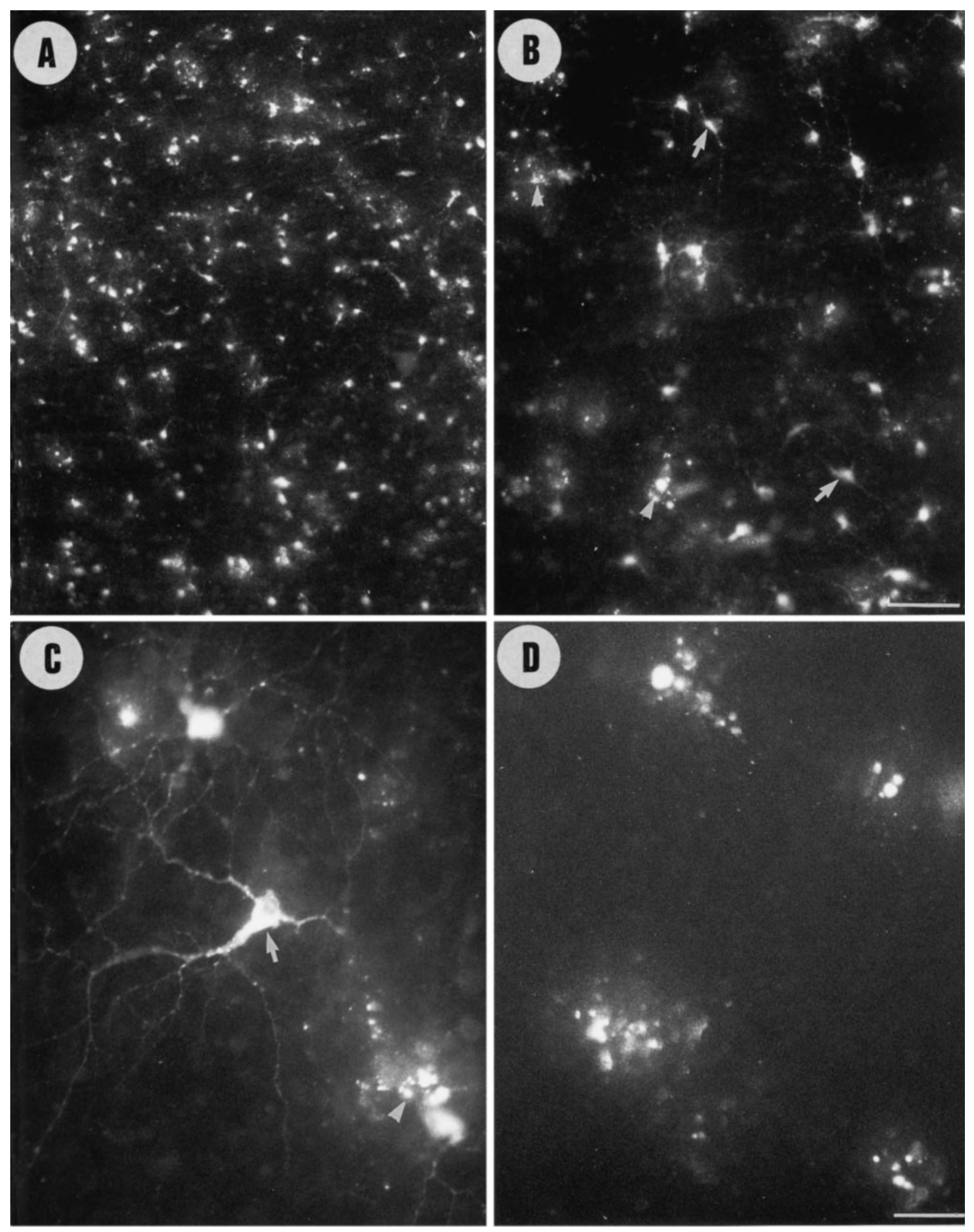

Figure 7. Retrograde labeling of GCs contributing to the retino-retinal projection. $A$, Low-magnification fluorescence photomicrograph showing the cells labeled from E10 to E14 taken from the nasal retina shown in Figure $5 C$. Note the high density of cells. $B$, Higher magnification within the same area showing typical GCs (arrow) but also numerous apoptotic profiles (arrowheads). C) Higher magnification allows detailed identification of the living cells (arrow) and dying cells (arrowheads) at different stages of apoptotic degradation. D, Region with only silhouettes of dead cells with multiple apoptotic bodies at E16. Scale bar: $A, 100 ; B, 50 \mu \mathrm{m} ; C, D, 25 \mu \mathrm{m}$. 


\section{Developmental course of apoptosis}

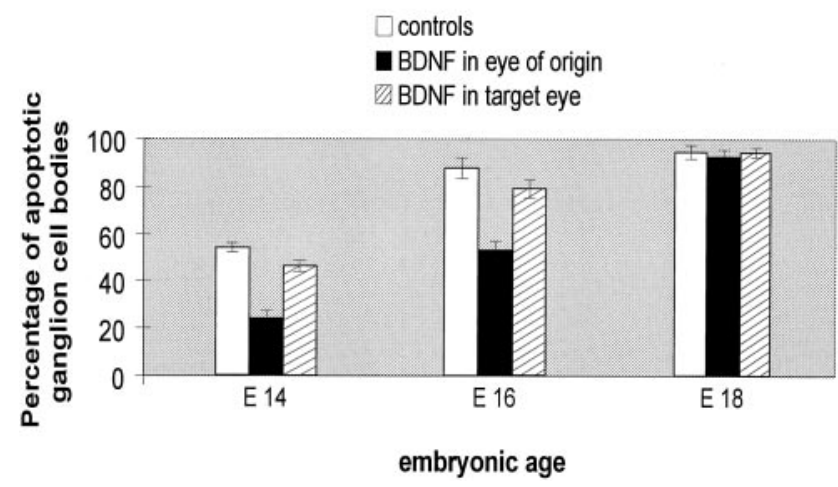

Figure 8. Graph corroborating the proportion of apoptotic cells at three typical embryonic days of investigation in normal and BDNF-treated embryos. At all stages, BDNF reduced the proportion of apoptotic silhouettes but was unable to rescue cells beyond the period of cell death (E18). There was a significant difference $(p<0.01$, Student's $t$ test) between embryos that received BDNF in the retina analyzed at both P14 and $\mathrm{P} 16$ and those that received $\mathrm{BDNF}$ in the retina contralateral to analysis.

death. Neither vital nor dying retino-retinal GCs were observed at posthatched stages [injected at postnatal day 6 (P6) and analyzed at P11], indicating a complete elimination of this projection during embryogenesis.

Prelabeling of GCs such as those forming the retino-retinal projection resulted in phagocytosis-dependent staining of the glial elements, which were responsible for clearance of the cellular debris. In the developing chick retina, fluorescent ganglion cell debris was internalized by radial Müller glia, which become labeled throughout the depth of the retina (Fig. 9A, $B$, Table 1). No labeled interneurons and virtually no microglial cells were visible until embryonic day E14 (Table 1). First indications of cells with typical microglia-like silhouettes coexisting with Müller cells were obtained at E16 (Fig. 9B). Both ameboid microglial cells in the optic fiber layer (Fig. $9 C, D)$ and ramified microglial cells in the ganglion cell layer (Fig. 9E,F) appeared labeled with the fluorescent dye and were associated with GCs undergoing cell death. At this stage labeled Müller cells coexisted with microglial cells (Fig. 9B). When labeled at E10 from the contralateral eye and observed at E18, no living GCs but only labeled microglial cells in whole mounts (Fig. 9G) and in sections (Fig. $9 H$ ) could be observed within the nasal retina. The density and distribution of microglial cells (Fig. 9G, Table 1) reflect the previous occupation of this area with GCs (compare with Fig. $7 A$ ), which have died at E18 and have been removed by phagocytosis.

\section{Dendritogenesis and "dendrito-apoptosis" within the retino-retinal projection}

Of the two carbocyanine dyes used, 4Di10-ASP appeared most suitable to completely label the dendritic extensions of retrogradely filled GCs. The earliest dendritic processes were observed at E6 in the central retina, although most of the GCs had small or no dendrites (Fig. $1 C$ ). Elaborated dendritic branching was found across the labeled retina at E9-E10 (Fig. 10A,B). The patterns of ramification were indistinguishable from cells forming the retino-tectal projection (Vanselow et al., 1990). Similar dendritic territories were observed at E14, a stage characterized by cataclysmic cell death. This death was also reflected in the mor- phology of dendrites. Almost coincidental with perikaryal condensation and onset of degeneration, irregular thickenings and dense varicosities appeared along the dendritic processes (Fig. $10 C)$ as indicators of death. Dendritic spines and small branches were disconnected from the main branches, giving a picture of the true "apoptosis" originally described as the "fall of dendritic leaves" (Kerr et al., 1972). More advanced stages of such dendritic regression (dendrito-apoptosis) were the collapse of the typical shape and replacement with fluorescent apoptotic products (Fig. $10 D, E)$.

Few GCs survived until E16, the period characterized by almost complete ganglion cell death. Of 113 GCs counted in five retinas at this stage, the vast majority (102) displayed the stereotypic shapes of dendrites shown in Figure 11. The cells had large somata, thickened primary dendrites, and dense patterns of ramification reminiscent of the groups V (Fig. 11E) and VII (Fig. $11 A, B)$ GCs labeled with DiI in the chick retina (Vanselow et al., 1990). The fewer small cells (Fig. 11C,D) were reminiscent of groups Ib (Fig. 11C) and Ia (Fig. 11D), cells which usually project to the tectum. This pattern of ramification was morphologically unaltered in embryos treated with BDNF, although the direct treatment of cell bodies resulted in more spiny and bushy dendrites (Fig. $11 F$ ). Although not quantified, several other types and subtypes of GCs were observed at E14 and later, indicating that no particular subpopulation or a distinctive type of retinal $\mathrm{GC}$ is committed to form the retino-retinal projection.

\section{Double labeling of retinal GC from the tectum and the contralateral retina}

The survival of a few GCs forming the retino-retinal projection in young rats has been attributed to formation of collaterals projecting to central targets such as the thalamic nuclei and the superior colliculus (Müller and Holländer, 1988). To investigate a potential collateralization in the embryonic chick, 4Di10-ASP was injected into the right eye at E10, and Fluorogold was injected into the right tectum (Fig. $12 C)$. Analysis of the left retina $(n=$ $7)$ at E14 $(n=3)$ and E16 $(n=4)$ revealed both massive labeling of GCs projecting into the tectum (Fig. $12 A, C$ ) and cells projecting into the contralateral retina (Fig. $12 B, D$ ). It appeared that of hundreds ( $>500$ observed in both filters) of identified retinoretinal GCs, not even a single cell displayed double labeling, thus indicating the lack of collateral formation at the optic chiasm. The fact that no GCs were labeled at the final stages of development and after hatching also makes it unlikely that the collateral formation is a mechanism of cell stabilization and survival in this system.

\section{DISCUSSION}

The present investigation sheds light onto certain aspects of the embryonic retino-retinal projection in the chick. Figure 13 summarizes graphically the data obtained in this study and illustrates the major steps of development and disappearance of the retinoretinal projection.

\section{Topological and quantitative aspects of the projection}

The first novel aspect of the present study is the appearance of a pronounced the retino-retinal projection with a total population of more than 2000 cells (Table 1), which connect the nasal hemiretina of each eye with the temporal retinal half of the partner eye (Fig. 13A-C). Neither the large number of retinoretinally projecting cells nor their selective location has been described in any species before. Bunt and Lund (1981) observed a variable but much lower number of GCs, which transiently 

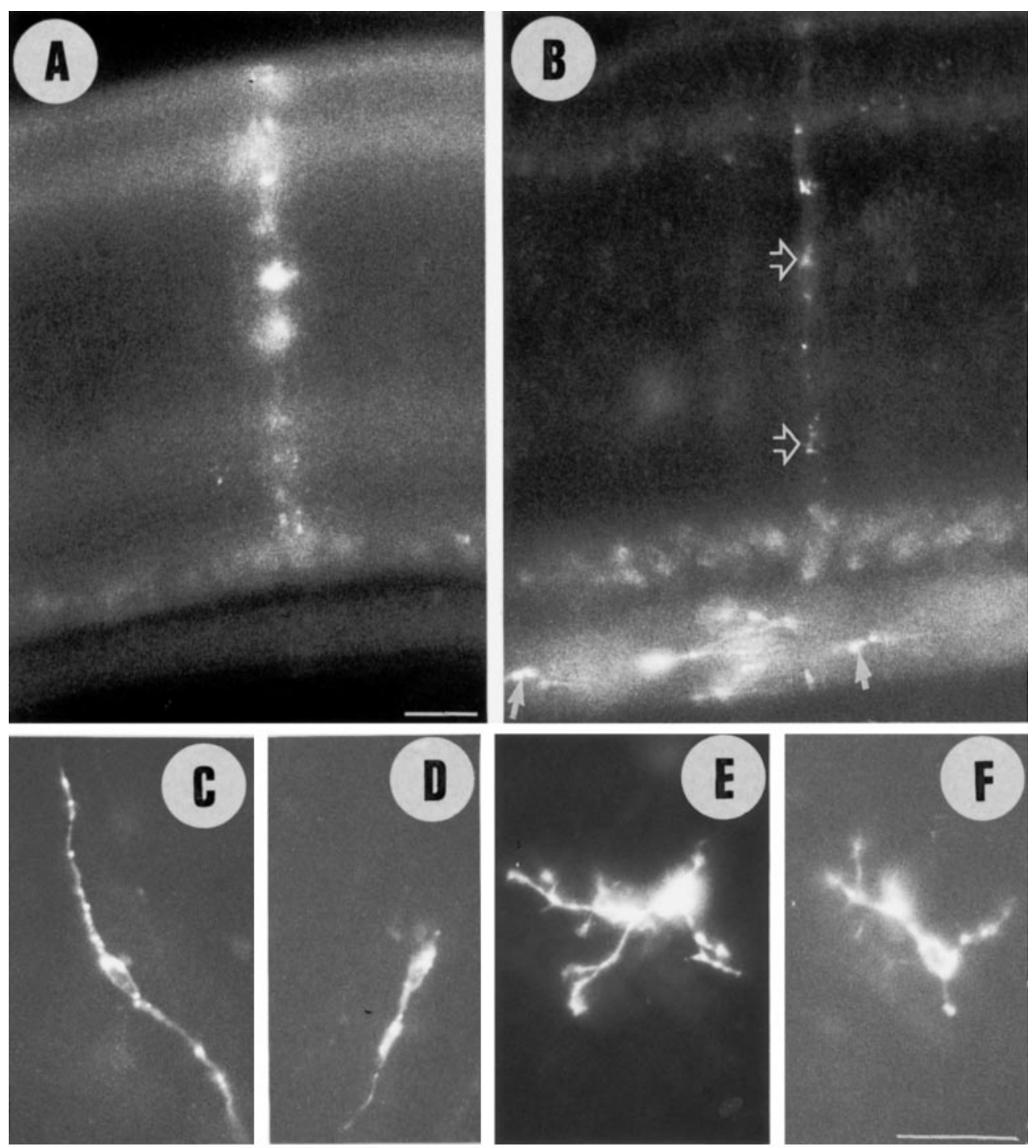

Figure 9. Apoptosis-dependent label-
ing of phagocytosing glial cells within the retina. A, Typical Müller cells associated with uptake of the fluorescent product at early stages of ganglion cell death (E14). B, Müller cells (arrowhead) and microglial cells (arrow) in the same section at E16. $C, D$, Ameboid microglial cells appearing within the nerve fiber layer at E16 and viewed in the whole-mounted retina. $E, F$, Ramified microglial cells in the ganglion cell layer at E16. $G$, Photograph taken from a nasal retinal whole mount after injection at E10 (before cell death) and examination at E18 (after cell death). Note the regular, typical distribution of microglial cells, which have been labeled after phagocytosis of GCs contributing to the retino-retinal projection. $H$, Section through the retina at E18 shows microglial cells (arrows) within the GCL and IPL. In all photographed sections OFL is toward the bottom. Scale bars: $A-F, 25$ $\mu \mathrm{m} ; G, 50 \mu \mathrm{m}$.
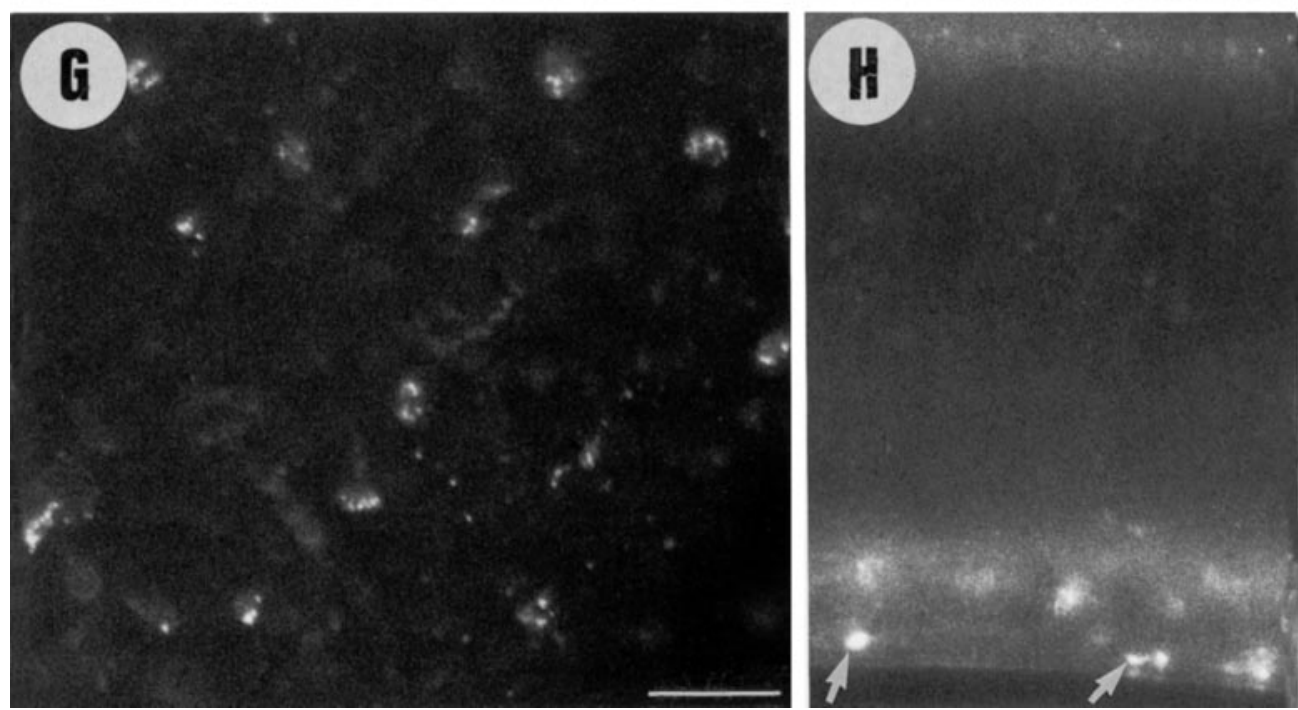

projected into the other eye in the embryonic rat. Müller and Holländer (1988) observed that an average of 130 GCs connect the two retinas in rats postnatally, and a similar number appear in the rabbit. In relation to the total population of GCs in rats
( $\sim 100,000 \mathrm{GCs}$ ), this number is comparable with that of chicken. Toth and Straznicky (1989) described an average of 12 GCs per retina projecting into the contralateral eye in three anuran species. In contrast to mammals, these cells survived throughout the 

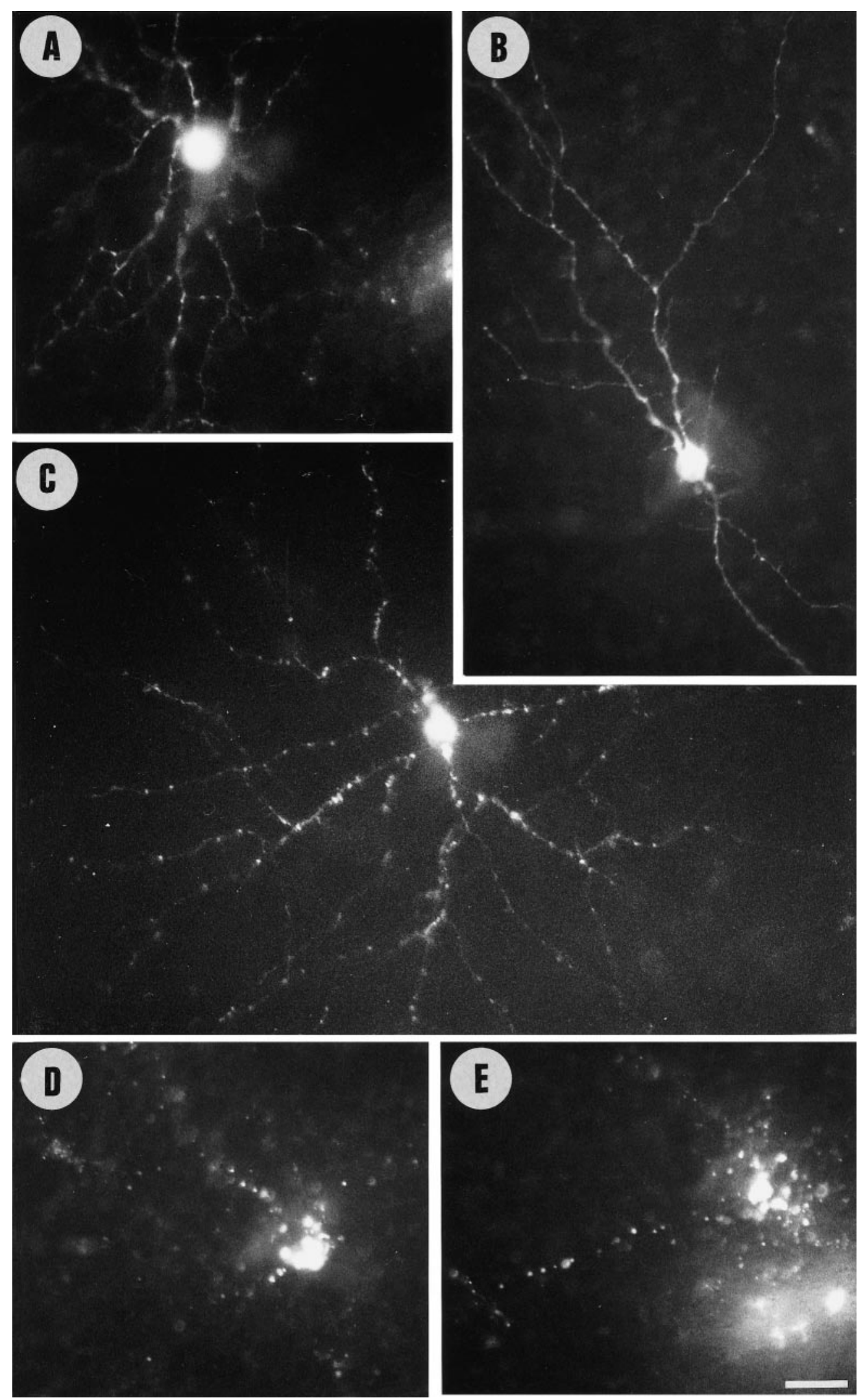

Figure 10. Visualization of dendritogenesis and -apoptosis within the retino-retinal projection. $A, B$, Typical dendrites at E9. $C$, Onset of karyoapoptosis (condensed, irregularly shaped perikaryon) and dendritoapoptosis (irregular varicosities, swellings along the branches) in a cell at E14. D, E, Advanced stages of apoptosis including both the perikarya and the dendrites at E14. Scale bar, $25 \mu \mathrm{m}$.

entire lifespan of the animals. The explanation that these were misrouted axons was substantiated with studies on regenerating optic nerves in frogs, which showed that a large population of axons from one eye entered the contralateral optic nerve but not the retina (Bohn and Stelzner, 1981a-c).
A first explanation for the misrouting may be that the projection represents a phylogenetic but transient remnant of the decussation of nasal but not temporal fibers in higher vertebrates such as primates. In such species, including humans, several rearrangements take place at the chiasm until the final adult 

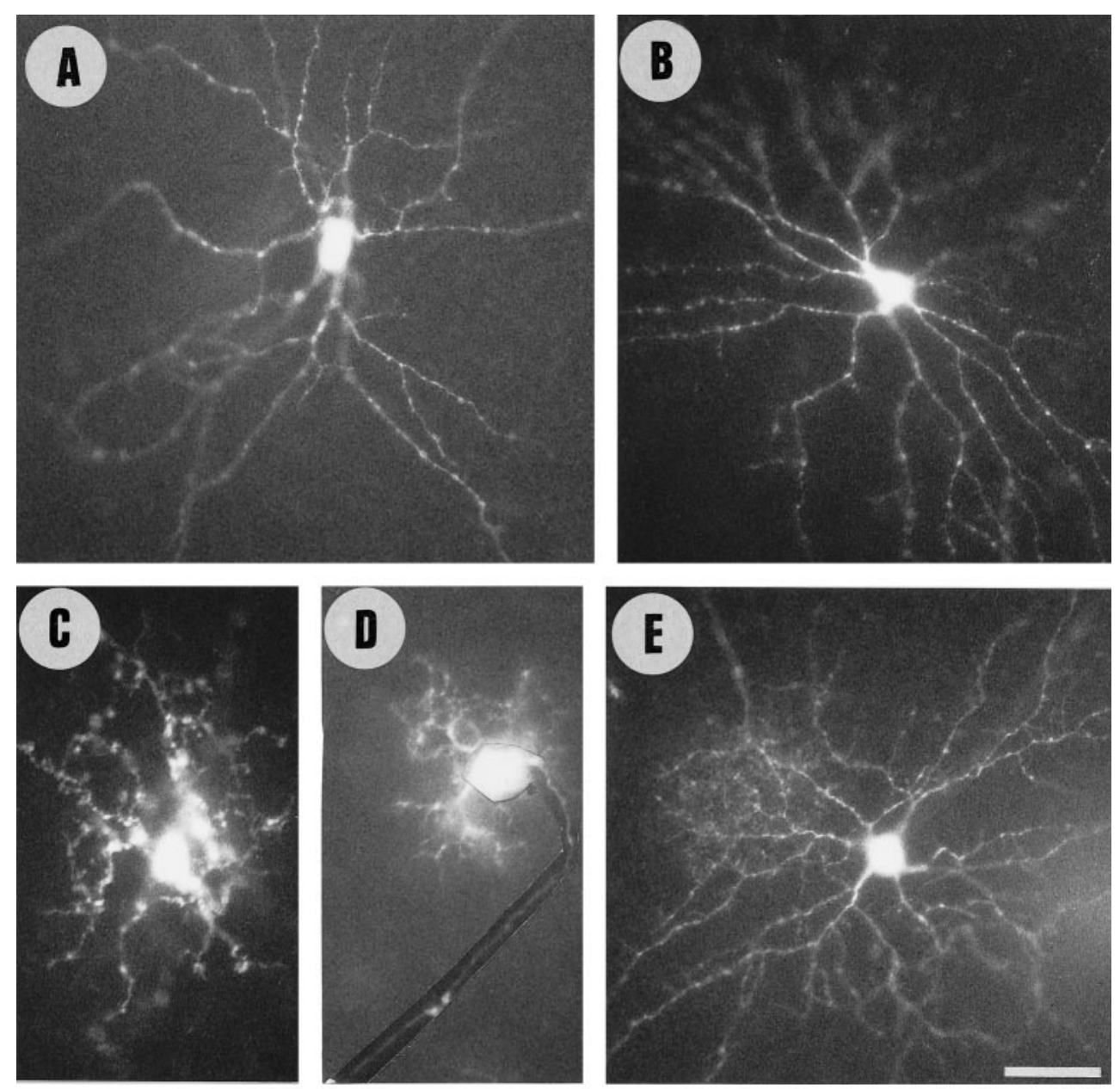

Figure 11. Branching patterns, sizes, and typification of GCs contributing to the retino-retinal projection at E16. $A-C$, Large cells with elaborate dendrites classified as group VII cells according to Vanselow et al. (1990). C, D, Small cells with small and bushy dendritic arbors corresponding to groups Ia and Ib. $E$, Large cell of group $\mathrm{V}$ with large dendrite and elaborate ramifications. $F$, Cell of group $\mathrm{V}$ after BDNF injection into the right eye and retrograde staining from left eye. Note the multiple spines along the dendritic branches. Scale bars: $A-E, 50 \mu \mathrm{m}$; F, $25 \mu \mathrm{m}$.

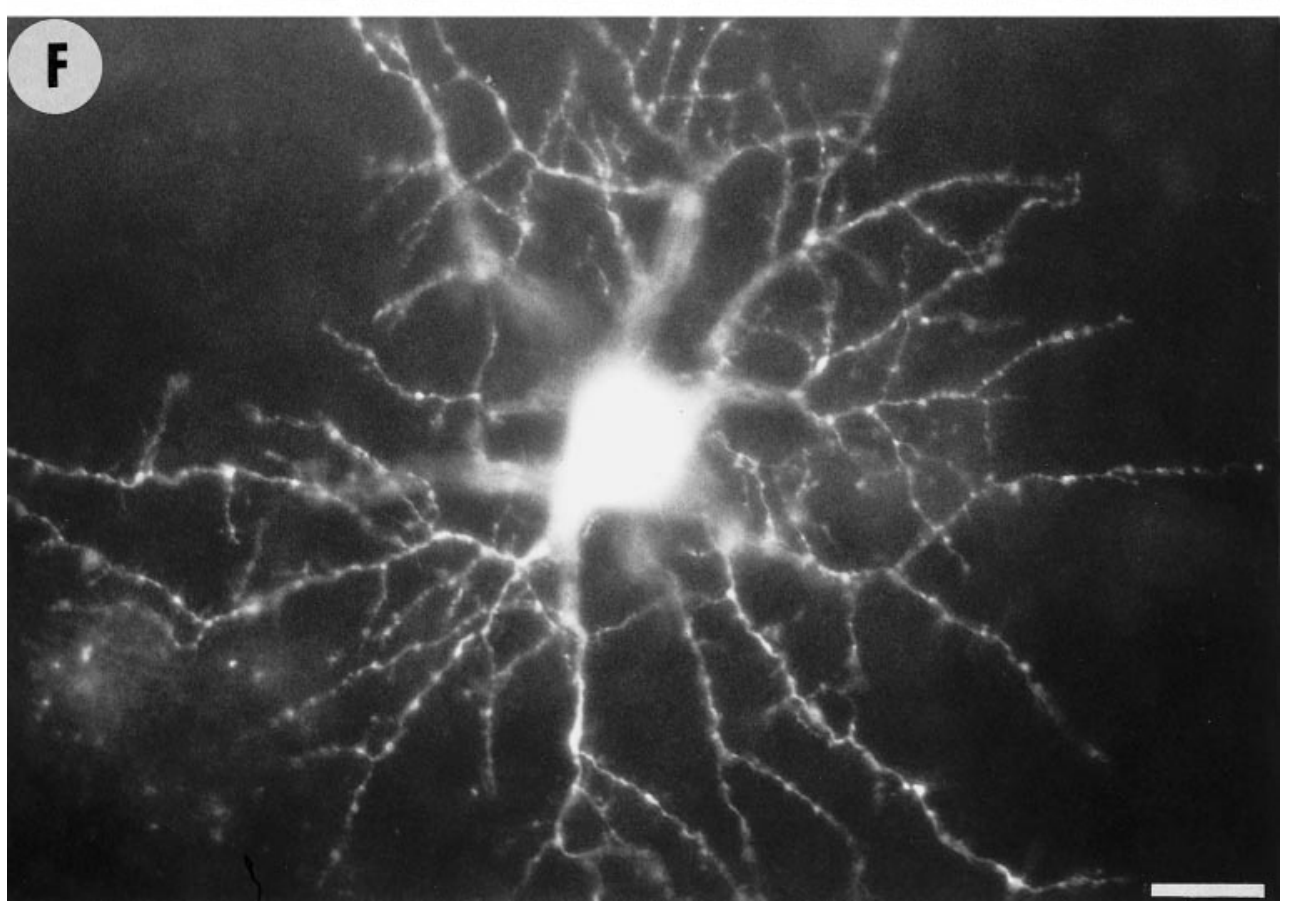

configuration is reached (Guillery et al., 1995). These topographic rearrangements may occur in other species with loss of retino-topic order at the chiasm such as nonprimates (Wizenmann et al., 1993; Chan and Guillery, 1994), and the chick
(Halfter, 1987; Drenhaus and Rager, 1994). Evidence of chiasmal misrouting exists in human albino neonates (Apkarian et al., 1991), whereas normal humans form the so-called Wilbrand's knee (Horton, 1997), which is a loop of nasal fibers into the 

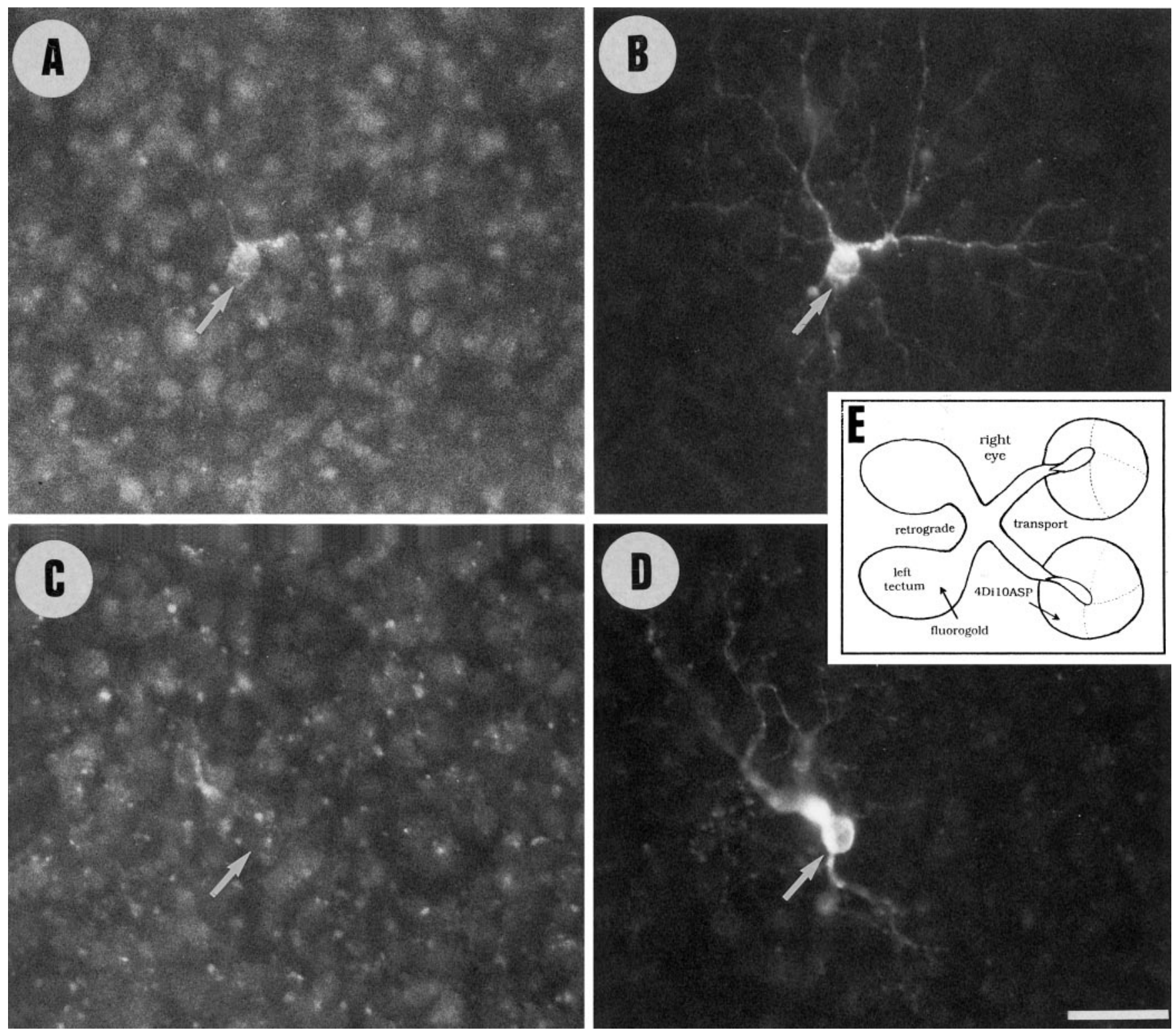

Figure 12. The schematic inset $(E)$ shows the experimental setup to label GCs, which may have formed two collaterals, one to the tectum (Fluorogold) and the other to the contralateral retina (4Di-10ASP). $A, B$, Same retinal region at E16 with Fluorogold-loaded GCs $(A)$ from the tectum and one single ganglion cell $(B)$ loaded with 4Di-10ASP from the contralateral retina. Arrows point to the position of this cell. Part of the cell is visible within the Fluorogold filter because of the selection of the emission window, but the cell is not double-labeled. $C$, $D$, Similar setup, with the single cell in $D$ containing only 4Di-10ASP, thus indicating no collateral formation to the tectum, because it remained unlabeled with Fluorogold (arrows). Scale bar, $25 \mu \mathrm{m}$.

contralateral optic nerve before they cross to the contralateral optic tract. However, there is no evidence yet that human albinos possess a transient or a persisting retino-retinal pathway.

A second explanation for growth of axons into the partner eye could be associated with the unique feature of avians with centrifugal fibers originating in the ION to innervate the retina (Clarke et al., 1976; Cowan and Clarke, 1976; Catsicas et al., 1987; von-Bartheld et al., 1994, 1996). These fibers could be guided to the retina by the retino-retinal pathway while interacting with them at the chiasm and within the optic nerve. This would imply a "template" function, as postulated by O'Leary and Thanos (1985), for those axons growing from the ION along the medial border of the tectum between E6 and E8 (Fig. 13A) and for those tecto-isthmic axons after a transient projection from the
ION toward the tectum (Wizenmann and Thanos, 1990). Doublelabeling experiments at the ION and retina show that centrifugal axons and retino-retinal axons follow identical routes beyond the chiasm. Then, by traversing within the optic nerve, they exit from the optic fissure with identical patterns of intraretinal distribution and with a predominance of orientation toward the temporal hemiretina. The coincidential features of the two projections support the hypothesis of a template function of the retino-retinal axons. In contrast to retino-retinal axons, which are shown in the present work not to form successful terminal arbors, ION axons form terminal arbors and connect the nucleus with amacrines and displaced GCs of the contralateral retina (Maturana and Frenk, 1965).

A plausible third explanation is that misrouting of axons at the 
A
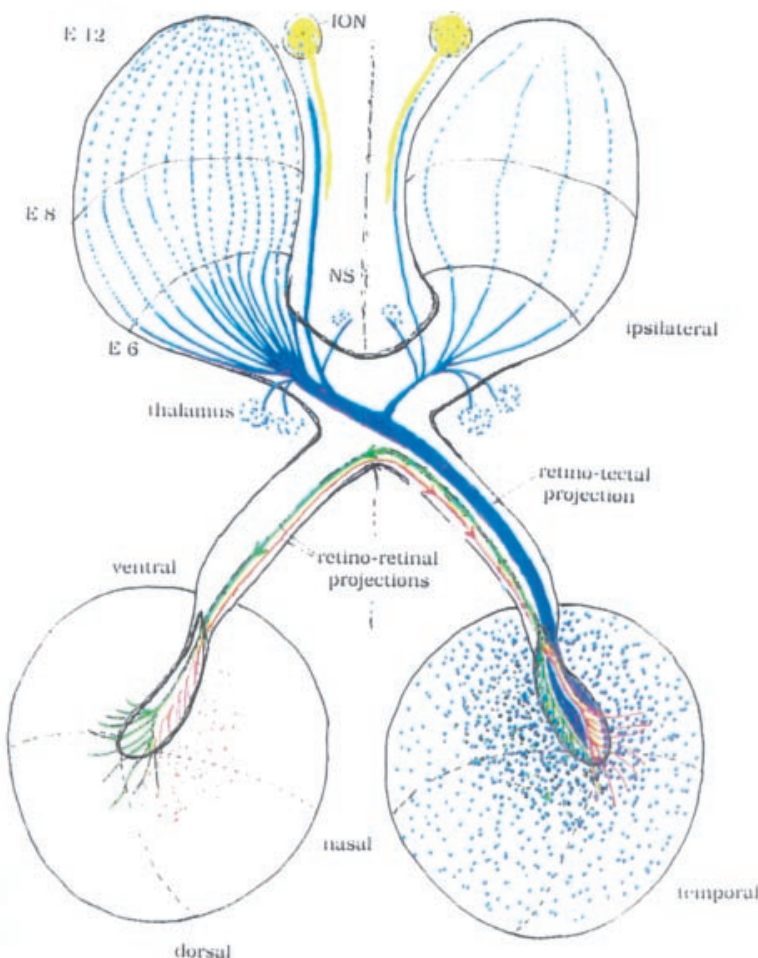

lorsal

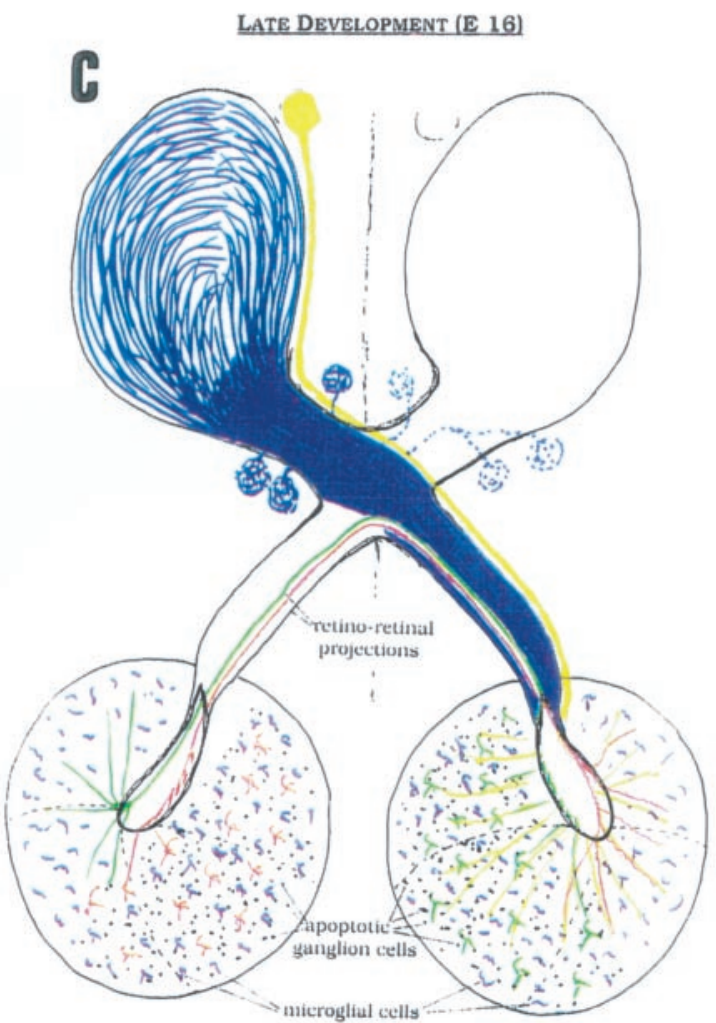

B

MIDDLE DEVELOPMENT (E 14)
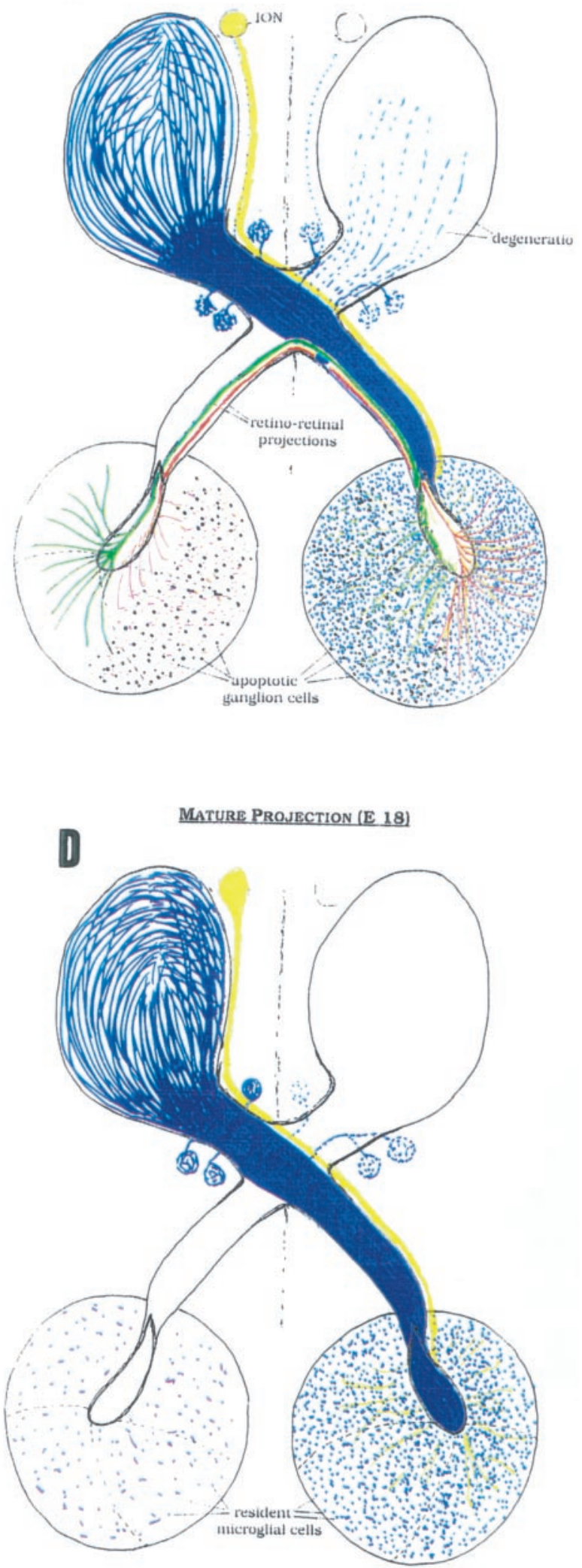

Figure 13. Summarizing presentation of the development and degeneration of the reciprocal retino-retinal projections in the chick embryo. $A$, Summary of the early stages (E6-E12) showing the central retino-fugal projections (blue) to the tecta, thalamus, and nucleus suprachiasmaticus (NS) and toward the area of ION (yellow). The reciprocal retino-retinal projections are marked in green and red and show from the beginning a hemiretinal topological projection from the nasal to the temporal half of the other site. $B$, At $\sim \mathrm{E} 14$, the retino-tectal topography is formed, the ipsilateral central retino-fugal projections degenerate, and the ION fibers have arrived at the retina. The retino-retinal axons are still present, whereas (Figure legend continues) 
chiasm is attributable to the lack of sufficient information for directed growth. Although the chiasm region itself is genetically controlled by expression of Pax-2 and Sonic hedgehog genes (Alvarez-Bolado et al., 1997), little is known about the mechanisms of axonal guidance control. Putative guidance molecules are cell adhesion molecules such as neural cell adhesion molecule (Thanos et al., 1984; Takeichi, 1990; Rager et al., 1996) expressed by the axons and by local neuroepithelial and glial cells (Navascués and Martin-Partido, 1990; Morissette and Carbonetto, 1995).

The fact that axons arriving at the retina of the contralateral eye are located within the temporal hemiretina implies that nasal axons of one retina may approach temporal axons from the other one at the chiasm or within the contralateral optic nerve. Doubleinjection studies with two different chromophores in either of the eyes are currently performed to reconstruct the exact relationship of the opposite projections within the optic nerves. So far, conclusive from the present work, fiber-fiber interactions seem to have no directional selectivity, because axons can apparently grow along each other both in the same direction and in the opposite one. Directionality of axonal growth determined by local cues (Silver, 1984; Navascués et al., 1987) does not seem absolutely sufficient for guidance of axons into the brain, and errors are possible. This was consistently observed in the chick (McLoon and Lund, 1982; O'Leary et al., 1983; Cowan et al., 1984) (present work), in the mouse (Godement et al., 1990; Sretavan, 1990), and in the rat (Horsburg and Sefton, 1986).

\section{The role of neurotrophic factors}

Another novel finding of the present study is the responsiveness of the transient retino-retinal cells to the injection of BDNF. This neurotrophic factor has been described to rescue cultured GCs from death (Johnson et al., 1986). In addition, BDNF can be internalized by binding to both the $\mathrm{p} 75$ and trkB receptors in the chick retina and retrogradely transported within the centrifugal fibers to rescue cells within the isthmo-optic nucleus (vonBartheld et al., 1996). Although it is still under discussion whether BDNF mediates autocrine and paracrine signaling within the developing visual system, trkB isoforms were expressed both within a subpopulation of retinal GCs and within retino-receptive centers (Garner et al., 1996). In the present system of retinoretinal cells it seemed unable to rescue the cells projecting to the partner retina beyond the period of normal cell death, although some delay in GC death was observed until E18. This may be well consistent with former observations in which maturating GCs lose their responsiveness to BDNF (Johnson et al., 1986). On the other hand, supply of BDNF to the ganglion cell bodies, but not directly to the growth cones, induced a remarkable penetration of the latter into deeper retinal layers and formation of elaborate branches. Exogeneously administered BDNF increased the survival of Xenopus laevis GCs, whereas immediate responses were observed at growth cones (Cohen-Cory et al., 1996). These data are confirmed by the present study, which, in addition, confirms that BDNF is produced within the retinal GCL rather than in areas of termination such as the tectum (Herzog and vonBartheld, 1998). The fact that the projection is transient despite terminal branching indicates that not branching itself but synap- togenesis is responsible for cell survival, and synaptic contacts are unlikely to be formed by ganglion cell axons growing into the retina. Thus, although the projection responds to BDNF, it does not reverse its transient character.

\section{Apoptosis and clearance of dying cells}

Involvement of microglial cells in phagocytosis of dying GCs is described in the retina of various species and occurs both during development and during induced degenerations (for review, see Thanos et al., 1994). As observed by using the quail-specific antibody QH1, microglial cells form a dense network in the avian retina, too (Navascués et al., 1994). In the developing quail retina QH1-positive macrophages are extravasated at the pecten and move transvitreally or along the vitreo-retinal membrane toward the retina. Microglial precursors migrate along the inner limiting membrane in contact with Müller cell endfeet to enter then the retinal tissue (Navascués et al., 1995). The earliest embryonic age with microglial cells within the ganglion cell layer was E9, and within the inner plexiform layer it was E12. Because the quail hatches at E16-E17, and the chick at hatches E21, the stage E9 of quail corresponds approximately to chick E13, and E12 of quail corresponds approximately to E16 of the chick. Therefore, it is not surprising that phagocytosing microglial cells are first observed at E16 in the present study. Although the lack of chickspecific antibodies is an impediment toward similar migration studies in the chick, there is no evidence that the microglial cells do not behave like the quail microglial cells. The present data confirm the observation of Navascués et al. (1995) that ingestion of cell debris starts after immigration and retinal invasion by microglial cells.

In contrast, the radial Müller cells have less frequently been linked to phagocytosis of dying cells. Penfold and Provis (1986) and Provis and Penfold (1988) reported for the first time that elimination of cell bodies and retinal axons is associated with Müller cells in the embryonic human retina. The close investment of GCs by Müller cells has been proposed as the reason why these cells perform phagocytosis (Stone et al., 1995; Egensperger et al., 1996). It is interesting that Müller cells perform phagocytosis at earlier stages of cell death (before E16), characterized by lack of phagocytotic microglial cells, and are later replaced by microglial cells. This cellular shift may be accompanied by a downregulation of cellular receptors for apoptotically produced ligands. A potential interaction resulting in such a regulation may be mediated by direct communication between immigrating microglia while contacting Müller cell endfeet. In conclusion, the data show that transient projections may be considered developmentally regulated events, whose potential role has not been unraveled yet. Such projections can serve as targets of neurotrophic factors and models for apoptosis and cellular clearance during development.

\section{REFERENCES}

Alvarez-Bolado G, Schwarz M, Gruss P (1997) PAX-2 in the chiasm. Cell Tissue Res 290:197-200.

Apkarian P, Eckhardt PG, van-Schooneveld MJ (1991) Detection of optic pathway misrouting in the human albino neonate. Neuropediatrics 22:211-215.

Barde YA, Edgar D, Thoenen H (1982) Purification of a new neurotrophic factor from the mammalian brain. EMBO J 1:549-553.

massive cell death occurs. $C$, At E16, microglial cells ( pink) are labeled by phagocytosis, vital GCs have differentiated dendrites, and axons are still visible within the nasal part of the contralateral retina. $D$, At E18 and after hatching, the projections between the retinas disappear, and the only cells reminiscent of completed cell death are microglial cells. Persistent projections to and from the central targets display mature patterns. 
Bohn RC, Stelzner DJ (1981a) The aberrant retino-retinal projection during optic nerve regeneration in the frog. I. Time course of formation and cells of origin. J Comp Neurol 196:605-620.

Bohn RC, Stelzner DJ (1981b) The aberrant retino-retinal projection during optic nerve regeneration in the frog. II. Anterograde labelling with horseradish peroxidase. J Comp Neurol 196:621-632.

Bohn RC, Stelzner DJ (1981c) The aberrant retino-retinal projection during optic nerve regeneration in the frog. III. Effects of crushing both nerves. J Comp Neurol 196:633-643.

Boya J, Calvo J, Prado A (1979) The origin of microglial cells. J Anat 129:177-186.

Brockhaus J, Möller T, Kettenmann H (1996) Phagocytosing ameboid microglial cells studied in a mouse corpus callosum slice preparation. Glia 16:81-90.

Bunt SM, Lund RD (1981) Development of a transient retino-retinal pathway in hooded and albino rats. Brain Res 211:399-404.

Catsicas S, Thanos S, Clarke PG (1987) Major role for neuronal death during brain development: refinement of topographical connections. Proc Natl Acad Sci USA 84:8165-8168.

Chan SO, Guillery RW (1994) Changes in fiber order in the optic nerve and tract of rat embryos. J Comp Neurol 344:20-32.

Clarke PG, Rogers LA, Cowan WM (1976) The time of origin and the pattern of survival of neurons in the isthmo-optic nucleus of the chick. J Comp Neurol 167:125-142.

Cohen-Cory S, Escandon E, Faser S (1996) The cellular patterns of $\mathrm{BDNF}$ and trkB expression suggest multiple roles for BDNF during Xenopus visual system development. Dev Biol 179:102-105.

Cowan WM, Clarke PG (1976) The development of the isthmo-optic nucleus. Brain Behav Evol 13:345-375.

Cowan WM, Fawcett JW, O'Leary DDM, Stanfied BB (1984) Regressive events in neurogenesis. Science 225:1258-1265.

Cuadros MA, Moujahid A, Quesada A, Navascués J (1994) Development of microglia in the quail optic tectum. J Comp Neurol 348:207-224.

Del Rio JA, Heimrich B, Borrell V, Forster E, Drakew A, Alcantara S, Nakajimam K, Miyata T, Ogawa M, Mikoshiba K, Derer P, Frotscher M, Soriano E (1997) A role of Cajal-Retzius cells and reelin in the development of hippocampal connections. Nature 385:23-24.

Drenhaus U, Rager G (1994) Formation of alternating tiers in the optic chiasm of the chick embryo. Anat Rec 240:555-571.

Dütting D, Thanos S (1995) Early determination of nasal-temporal retinotopic specificity in the eye anlage of the chick embryo. Dev Biol 167:263-281.

Egensperger R, Maslim J, Biti S, Holländer H, Stone J (1996) Fate of DANN from retinal cells during development: uptake by microglia and macroglia (Müller cells). Dev Brain Res 97:1-8.

Garner AS, Menegay HJ, Boeshore KL, Xie XY, Voci JM, Johnson JE, Large TH (1996) Expression of TrkB receptor isoforms in the developing avian visual system. J Neurosci 16:1740-1752.

Godement P, Salaün J, Mason CA (1990) Retinal axon pathfinding in the optic chiasm: divergence of crossed and uncrossed fibers. Neuron 5:173-186.

Guillery RW, Mason CA, Taylor JS (1995) Developmental determinants at the mammalian optic chiasm. J Neurosci 15:4727-4737.

Halfter W (1987) Anterograde tracing of retinal axons in the avian embryo with low molecular weight derivatives of biotin. Dev Biol 119:322-335.

Hamburger V, Hamilton HL (1951) A series of normal stages in the development of the chick embryo. J Morphol 88:49-92.

Herzog K-H, von-Bartheld CS (1998) Contributions of the optic tectum and the retina as sources of brain-derived neurotrophic factor for retinal GCs in the chick embryo. J Neurosci 18:2891-2906.

Hofer MM, Barde YA (1988) Brain-derived neurotrophic factor prevents neuronal death in vivo. Nature 331:261-262.

Horsburg GM, Sefton AJ (1986) The early development of the optic nerve and chiasm in the embryonic rat. J Comp Neurol 243:547-560.

Horton JC (1997) Wilbrand's knee of the primate optic chiasm is an artefact of monocular enucleation. Trans Am Ophthalmol Soc 95:579-609.

Innocenti GM (1981) Growth and reshaping of axons in the establishment of visual calosal connections. Science 212:824-827.

Johnson JD, Barde YA, Schwab ME, Thoenen H (1986) Brain-derived neurotrophic factor supports the survival of cultured rat retinal GCs. J Neurosci 6:3031-3038.

Kerr JFR, Willy AH, Currie AR (1972) Apoptosis: a basic biological phenomenon with wide-ranging implications in tissue kinetics. $\mathrm{Br} \mathrm{J}$ Cancer 26:239-257.

Koester SE, O'Leary DD (1994) Axons of early generated neurons in cingulated cortex pioneer the corpus callosum. J Neurosci 14:6608-6620.

Maturana HR, Frenk S (1965) Synaptic connections of the centrifugal fibers in the pigeon retina. Science 150:359-361.

McLoon S, Lund RD (1982) Transient retinofugal pathways in the developing chick. Exp Brain Res 45:277-284.

Morissette N, Carbonetto S (1995) Laminin $\alpha 2$ chain (M-chain) is found within the pathway of avian and murine retinal projections. J Neurosci 15:8067-8082.

Moujahid A, Navascués J, Marín-Teva JL, Cuadros MA (1996) Macrophages during avian optic nerve development: relationship to cell death and differentiation into microglia. Anat Embryol 193:131-144.

Müller M, Holländer H (1988) A small population of retinal GCs projecting to the retina of the other eye. An experimental study in the rat and the rabbit. Exp Brain Res 71:611-617.

Nakamura H, O'Leary DDM (1989) Inaccuracies in initial growth and arborization of chick retinotectal axons followed by course corrections and axon remodeling to develop topographic order. J Neurosci 9:3776-3795.

Navascués J, Martin-Partido G (1990) Glial cells in the optic chiasm arise from the suboptic necrotic centers of the diencephalon floor: morphological evidence in the chick embryo. Neursci Lett 120:62-65.

Navascués J, Rodriguez-Gallardo L, García-Martinez V, Alvarez IS (1987) Extra-axonal environment and fibre directionality in the early development of the chick embryo optic chiasm: a light and scanning electron microscopic study. J Neurocytol 16:299-310.

Navascués J, Moujahid A, Quesada A, Cuadros MA (1994) Microglia in the avian retina: immunocytochemical demonstration in the adult quail. J Comp Neurol 350:171-186.

Navascués J, Moujahid A, Almendros A, Marin-Teva JL, Cuadros MA (1995) Origin of microglia in the quail retina: central-to-peripheral and vitreal-to-scleral migration of microglial precursors during development. J Comp Neurol 354:209-228.

O'Leary DD, Terashima T (1988) Cortical axons branch to multiple subcortical targets by interstitial axons budding: implications for target recognition and "waiting periods." Neuron 1:901-910.

O'Leary DD, Thanos S (1985) A transient retinofugal projection and its possible role in guidance of centrifugal axons to the retina. Anat Rec 211:242.

O'Leary DD, Gerfen CR, Cowan WM (1983) The development and restriction of the ipsilateral retinofugal projection in the chick. Dev Brain Res 10:93-109.

O'Leary DD, Ruff NL, Dyck RH (1994) Development, critical period plasticity, and adult reorganizations of mammalian somatosensory systems. Curr Opin Neurobiol 4:534-544.

Orentas DM, Miller RH (1996) A novel form of migration of glial precursors. Glia 16:27-39.

Penfold PL, Provis JM (1986) Cell death in the development of the human retina: phagocytosis of pyknotic and apoptotic bodies by retinal cells. Graefes Arch Clin Exp Ophthalmol 224:549-553.

Provis JM, Penfold PL (1988) Cell death and the elimination of retinal axons during development. Prog Nerurobiol 31:331-347.

Rager G, Morino P, Schnitzer J, Sondergger P (1996) Expression of the axonal cell adhesion molecules axonin-1 and $\mathrm{Ng}$-CAM during the development of the chick retinotectal system. J Comp Nerurol 365:594-609.

Silver J (1984) Studies on the factors that govern directionality of axonal growth in the embryonic optic nerve and at the chiasm of mice. J Comp Neurosci 223:238-251.

Simon DK, Roskies AL, O'Leary DD (1994) Plasticity in the development of topographic order in the mammalian retinocollicular projection. Dev Biol 162:384-393.

Sretavan DW (1990) Specific routing of retinal ganglion cell axons at the mammalian optic chiasm during development. J Neurosci 10:1995-2007.

Stone J, Makarov F, Holländer H (1995) The glial investment of the somas and axons of retinal GCs. Vis Neurosci 12:273-279.

Takeichi M (1990) Cadherins: a molecular family important in selective cell-cell adhesion. Annu Rev Biochem 59:237-252.

Tennant M, Bruce SR, Bazley LD (1993) Survival of GCs which form the retino-retinal projection during optic nerve regeneration in the frog. Vis Neurosci 10:681-686. 
Thanos S, Bonhoeffer F (1984) Development of the transient ipsilateral retinotectal projection in the chick embryo: a numerical fluorescencemicroscopic analysis. J Comp Neurol 224:407-414.

Thanos S, Bonhoeffer F (1987) Axonal arborization in the developing chick retinotectal system. J Comp Neurol 261:155-164.

Thanos S, Dütting D (1987) Plasticity in the developing chick visual system: topography and maintenance of experimentally induced ipsilateral projections. J Comp Neurol 278:303-311.

Thanos S, Bonhoeffer F, Rutishauser U (1984) Fiber-fiber interactions and tectal cues influence the development of the chicken retinotectal projection. Proc Natl Acad Sci USA 81:1906-1910.

Thanos S, Vanselow J, Mey M (1992) GCs in the juveline chick retina and their ability to regenerate axons in vitro. Exp Eye Res 54:377-391.

Thanos S, Kacza J, Seeger J, Mey M (1994) Old dyes for new scopes: the phagocytosis-dependent long-term fluorescence labelling of microglial cells in vivo. Trends Neurosci 17:177-182.

Toth P, Straznicky C (1989) Retino-retinal projections in three anuran species. Neurosci Lett 104:43-47.

Tsong IG, Dreher B (1987) The development of the corticotectal path- way in the albino rat: transient projections from the visual and motor cortices. Neurosci Lett 80:275-282.

Vanselow J, Dütting D, Thanos S (1990) Target dependence of chick retinal GCs during embryogenesis: cell survival and dendritic development. J Comp Neurol 295:235-247.

von-Bartheld CS, Kinoshita Y, Prevette D, Yin QW, Oppenheim RW, Bothwell M (1994) Positive and negative effects of neurotrophins on the isthmo-optic nucleus in chick embryos. Neuron 12:639-654.

von-Bartheld CS, Williams R, Lefcort F, Clary DO Reichardt LF, Bothwell M (1996) Retrograde transport of neurotrophins from the eye to the brain in chick embryos: roles of the p57NTR and trkB receptors. J Neurosci 16:2995-3008.

Wizenmann A, Thanos S (1990) The developing chick isthmo-optic nucleus forms a transient efferent projection to the optic tectum. Neurosci Lett 113:241-246.

Wizenmann A, Thanos S, Boxberg Y, Bonhoeffer F (1993) Differential reaction of crossing and non-crossing rat retinal axons on cell membrane preparations form the chiasm midline: an in vitro study. Development 117:725-735. 